Western University Scholarship@Western

Centre for the Study of International Economic

Centre for the Study of International Economic

Relations Working Papers

Relations

1987

\title{
How Robust Is Applied General Equilibrium Analysis?
}

Glenn W. Harrison

Richard Jones

LarryJ. Kimbell

Randall Wigle

Follow this and additional works at: https://ir.lib.uwo.ca/economicscsier_wp

Part of the Economics Commons

Citation of this paper:

Harrison, Glenn W., Richard Jones, Larry J. Kimbell, Randall Wigle. "How Robust Is Applied General Equilibrium Analysis?." Centre for the Study of International Economic Relations Working Papers, 8707C. London, ON: Department of Economics, University of Western Ontario (1987). 
ISSN $\quad 0228-4235$

ISBN $\quad 0-7714-0860-9$

THE CENTRE FOR THE STUDY OF INTERNATIONAL ECONOMIC RELATIONS

WORKING PAPER NO. $8707 \mathrm{C}$

HOW ROBUST IS APPLIED GENERAL EQUILIBRIUM ANALYSIS?

\author{
Glenn W. Harrison \\ Richard Jones \\ Larry J. Kimbe11 \\ Randal1 Wigle
}

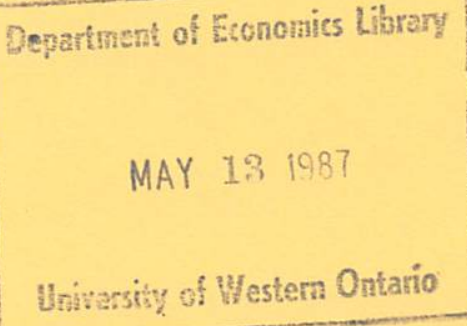

This paper contains preliminary findings from research work still in progress and should not be quoted without prior approval of the authors.

DEPARTMENT OF ECONOMICS

THE UNIVERSITY OF WESTERN ONTARIO

LONDON, CANADA

N6A $5 \mathrm{C} 2$ 
HOW ROBUST IS APPLIED GENERAL EQUILIBRIUM ANALYSIS?

by

Glenn W. Harrison

Richard Jones

Larry J. Kimbell

Randall Wigle*

May 1987

* University of Western Ontario; University of Western Ontario; UCLA; and University of Western Ontario, respectively. The U.S. National Science Foundation, The Reserve Bank of Australia, and the Social Sciences and Humanities Research Council of Canada have provided generous research support. We are grateful for helpful comments from participants at seminars at the Australian National University, an NBER Applied General Equilibrium Workshop, Stanford University, the University of Melbourne, the University of Western Australia, the University of Western Ontario, and the Winter Meetings of the Econometric Society. 


\section{ABSTRACT}

We argue that applied general equilibrium models should be routinely subject to systematic sensitivity analysis. Such an analysis will lead to policy simulations that capture, to some extent, the uncertainties involved in calibrating such models. Procedures for undertaking and reporting these analyses are proposed, and three illustrative applications presented.

Correspondence:

Glenn w. Harrison Department of Economics University of Western Ontario London, Ontario N6A 5C2 Canada

Phone: (519) 661-3493 (office)

(519) 661-3500 (Messages) 


\section{CONTENTS}

Page

1. THE ROBUSTNESS PROBLEM

2. A PROPOSED SOLUTION

2.1 Data Sources 9

2.2 Computational Aspects 11

2.3 Reporting Results 15

3. APPLICATIONS 19

3.1 "Are Developed Country Multilateral Tariff Reductions Necessarily Beneficial for the U.S."? 19

3.2 Comparison with Limited Sensitivity Analyses 26

3.3 Trade Liberalization and Industrial Organization 35

4. CONCLUDING REMARKS

APPENDIX A: LITERATURE REVIEW OF TRADE ELASTICITIES

APPENDIX B: ESTIMATION OF PRODUCTION ELASTICITIES

APPENDIX C: A COMPLETE UNCONDITIONAL SENSITIVITY ANALYSIS 


\section{THE ROBUSTNESS PROBLEM}

The early applied general equilibrium models of Scarf [1967] [1973] were modest in size (e.g., two or three producing sectors and two or three primary factors), qualitatively general in the sense of imposing very weak regularity conditions on model structure, and calibrated with hypothetical dat. Shoven and Whalley [1972], Shoven [1976] and Whalley [1977] provided the first small, qualitatively restrictive, policy-relevant applied general equilibrium (GE) models. Familiar functional forms were chosen for utility and production functions (e.g., single-level CES), techniques for empirical calibration were developed (viz., the notion of a benchmark equilibrium), and policy issues familiar from the Harberger [1962] [1966] tax incidence literature reexamined. More recent developments have extended this class to include reasonably large models with twenty or more producing sectors and/or four or more primary factors. Variations on the popular functional forms have also been adopted (e.g., multi-level CES, and LES demand systems) and a wide range of policy issues considered. Fullerton, Henderson and Shoven [1984] and Shoven and Whalley [1984] provide surveys of these developments. 1

The policy relevance of these models, and their avowedly empirical nature, render them open to casual criticism. Most economists are deeply familiar with their underlying neoclassical structure. We are therefore not concerned with their defense from criticisms based on rejection of that structure. This lack of concern stems from the absence of any well-defined alternative capable of addressing comparable policy issues at the empirical level desired. On the other hand, criticism based on suspicion of the particular empirical calibration adopted currently leads to non-systematic and/or ununiformed debate. The general techniques used to calibrate 
applied GE models are well known. ${ }^{2}$ Given, then, that users of such models are fairly well informed as to the various sources of data embodied in their simulations, how is one to identify the robustness of the results for some particular policy decision? Our response to this question is to urge a systematic sensitivity analysis of the policy simulations in question. This paper examines the problems that arise in such studies of the stochastic properties of applied GE models.

Our approach to the robustness problem employs natural priors as to the uncertainty about the parameter estimates of key elasticities in a GE model. These prior distributions are readily derived from the econometric studies that GE modellers currently use to obtain their point estimates from; the likelihood distributions of those studies provide the priors for our study. Alternative values of these estimates will typically have different likelihood values (the exception is a locally or globally diffuse distribution). Indeed the joint distribution of parameter estimates may be derived directly or indirectly, as discussed below.

Conditional on a set of such parameter estimates for elasticities, we may calibrate a GE model. Vary those elasticities and one obtains a distinct calibrated model. Each of these distinctly calibrated models can be simulated with some given policy shock (e.g., a tariff liberalization), and will typically generate distinct values for common endogenous variables (e.g., welfare).

Using the joint distribution over the priors that generated the series of distinctly calibrated models, we can weight the distinct endogenous variable values. Thus we end up with an implied distribution over the endogenous variables. This allows one to address many interesting policy questions. For example, what is the probability that the policy shock will 
have a positive impact on the endogenous variable? What is the median or mean impact? Is the distribution skewed? What confidence intervals does one place around the predicted impact?

We can identify three aspects of the robustness problem. The first is the issue of the comparative robustness or reliability of numerical GE analyses as against numerical partial equilibrium analyses of a given economic policy. Whalley [1975] raised this issue ${ }^{3}$, arguing that the results of "... partial equilibrium analysis seem to serve as unreliable approximation measures of the true changes in the economy" (p. 309; emphasis added). There is a maintained hypothesis that the GE model is the "true" model, conditional on point estimates for the relevant parameters. The unconditional robustness of the alternative approaches, assuming that we can define some weighting scheme for the various sets of parameter estimates and some measure of robustness applicable to both approaches, remains an open issue. One possible measure of robustness is the dispersion of simulation results about the benchmark solution (obtained using parameter point estimates) when there are given variations in parameter values $(e . g .$, one standard error either side of the point estimates). 4

The second aspect of the problem is the limited robustness of NGE models that is addressed when only performing local and "ad hoc", rather than global and "systematic", sensitivity analyses. In virtually every major policy applications of numerical GE models in recent years there has been some attempt to examine the sensitivity of results, albeit in a restricted parameter domain. ${ }^{5}$ Central tendency estimates of certain key parameters are perturbed by "large" changes one-by-one. Rarely is any explicit metric used to determine the significance of these changes, and even less frequently are 
combinations of such perturbations considered. The reasons for not engaging in or not reporting more exhaustive sensitivity analyses are twofold: the computational expense involved in obtaining the large number of required solutions, and the difficulty of efficiently reporting the results of so many simulations. Moreover, given the non-trivial labour involved in calibrating a detailed GE model just to some benchmark solution and the relatively high intellectual returns to exploring the response of the model to alternative policy perturbations (rather than alternative parameter pertubations), it is perhaps appropriate that these initial sensitivity analyses be modest.

The third aspect of the problem is the degree of robustness that may be attached to results from numerical GE simulations, in the sense of the confidence (degrees of belief) we have in those results. The benchmark numerical GE solution is conditional on certain parameter estimates, typically the point estimates. If there is some (stochastic) uncertainty about those estimates, there is some implied uncertainty about the benchmark calibration. Assume for the moment that one can represent the latter uncertainty in terms of a probability density function. The question posed here is then: are the results of some counterfactual policy simulation significantly different from the benchmark simulation, allowing for the parameter uncertainty of that benchmark? If the answer to such a question is "no", then we cannot attach much confidence to the differences between the benchmark and counterfactual solutions. Note that the answer may be "no" when looking at the policy impact on one endogenous variable (e.g., the relative price of capital) and "yes" when looking at the impact of the same policy on a different variable (e.g., labour use in a certain sector). The general objective, then, is to decide which policy inferences are robust to "reasonable" parameter variations and which inferences are not. 
In the next section we examine three dimensions of a solution to the robustness problem: sources of data, computational aspects, and the efficient reporting of results. In section 3 we present three illustrative applications of the proposed solution. The first re-examines the result in whalley and Wigle [1983] that multilateral tariff reductions are not necessarily beneficial for the United States. The second application evaluates the reliability of limited sensitivity analyses of the type popular in many studies. In the third application we evaluate the sensitivity of the sizeable trade liberalization welfare gains reported recently in an "industrial organization" GE model by Cox and Harris [1985] and Harris [1985] [1986]. Section 4 offers suggestions for future research.

\section{A PROPOSED SOLUTION}

The policy results of applied GE models are conditional on particular sets of parameter estimates. Typical practice is to employ the point estimate from an econometric model (e.g., the elasticities of factor substitution), survey (e.g., household expenditure shares) or hybrid estimation procedure (e.g., input-output coefficients generated by the RAS method). The starting point of our approach to the robustness problem in section 2.1 is therefore the assessment of the uncertainty that surrounds those point estimates.

Our approach to the robustness problem, to undertake a systematic sensitivity analysis, requires that we be able to solve applied GE models conditional on a large number of sets of parameter estimates. Although the exact number of solutions required depends on various factors, such as the number of uncertain parameters and the desired accuracy of the sensitivity 
analysis, it is likely to exceed the feasible upper bound using standard

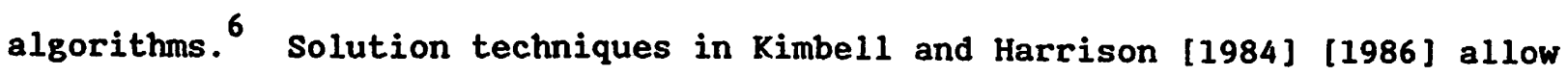
us to solve a certain "rich" class of applied GE models the required number of times. Approximation methods proposed in Pagan and Shannon [1985a] [1985b] and Vinod and Harrison [1987] may also dramatically reduce the required number of solutions. We evaluate in section 2.2 the computational feasibility of undertaking various forms of systematic sensitivity analysis.

Reporting the results of a systematic sensitivity analysis in an efficient and understandable manner is essential if those results are to be of any value. Two steps can assist in dramatically reducing the dimensionality of the reporting problem. The first is to decide on a subset of endogenous variables that one is concerned about, allowing one to disregard the results for the other variables. A typical example of such variables of interest include measures of individual and aggregate welfare loss (e.g., consumer's surplus). As a pragmatic matter, of course, it is possible to retain a small set of solution values for certain variables (e.g., factor prices) during the course of the sensitivity analysis computations and use those values in a subsequent analysis to regenerate complete GE solutions for all other endogenous variables. The second step in reducing the dimensionality of the reporting problem is to provide simple descriptive summary statistics about the distribution of solution values for the endogenous variables of interest. Section 2.3 addresses the question of efficient reporting.

\section{$2.1 \quad$ Data Sources}

Consider the two main sources of uncertainty about econometric estimates. The first is sampling uncertainty, and is reflected in a typical 
regression equation by the standard error (or "t-value") of the parameter estimate of interest. The second is specification uncertainty, and is of ten reflected in a given multiple regression equation by the covariance of parameter estimates (in turn reflecting, in part, the correlation of explanatory variables). Thus slight changes in the estimate adopted for one variable that is not of direct interest (e.g., a seasonal dummy) may affect the estimate for the variable of interest. Unfortunately, the existing econometric literature rarely publishes results in a form that permits inferences about such specification uncertainty (see Leamer and Leonard [1983] for further discussion).

In general we may think of all of the parameters of an applied GE model as having estimates that are interdependent. Thus the estimate of the elasticity of factor substitution in sector $i$ depends on the corresponding estimate for sector $j(i \neq j)$, on the vector of estimates of the output own-price demand elasticities, on the vector of estimated household expenditure shares, and so on. Consider then the implied covariance matrix of parameter estimates. Practical considerations based on the limited availability of parameter covariance estimates will force us to arbitrarily set many, if not all, of the off-diagonal elements of this matrix to zero. It is possible to construct covariance matrices for certain subsets of parameters, and therefore we are left with a block-diagonal covariance matrix for the complete set of parameters. In the remainder of this paper we shall focus on uncertain elasticity estimates, and assume that the available econometric literature provides information only on the variances of those estimates. Although it is natural to focus initially on the uncertainty of 
elasticities, we do not wish to suggest that the remaining data used to calibrate numerical GE models is any less certain.

\subsection{Computational Aspects}

A large number of parameters of popular numerical GE models are subject to uncertain estimation. In many cases we are able to obtain a well-defined (prior) probability density function for these estimates, allowing some statement as to the probability of values other than the point estimates. A sensitivity analysis with respect to any one of these parameters consists of examining the robustness of policy results of interest given a number of perturbations of the value of that parameter away from its point estimate. A systematic sensitivity analysis with respect to more than one parameter must take into account combinations of parameter perturbations. Clearly the latter sensitivity analysis will involve many more solutions to the NGE model than the former.

It is convenient to distinguish between a conditional systematic sensitivity analysis (CSSA) and an unconditional systematic sensitivity analysis (USSA). A CSSA is a series of simulations in which each parameter is perturbed from its point estimate a certain number of times (denoted $\mathbf{N}_{e}$ ), where we shall assume that $\mathrm{N}_{e}$ includes the point estimate, conditional on all other parameters being set only to their point estimate value. An USSA refers to perturbations of each parameter a certain number of times $\left(\mathbb{N}_{e}\right)$ conditional on all other parameters also being perturbed from their point estimate a certain number of times; thus the set of simulations is "unconditional". Clearly an USSA is more complete than a CSSA, but at a severe cost in terms of the number of required solutions. 
Consider any calculated result (e.g., a welfare impact) from a specified policy experiment (e.g., a tariff cut). In general we may denote this result as $Y=G(X, \theta)$ where $X$ is the vector describing the policy parameters, $\theta$ is the complete vector of exogenously specified elasticity values, and $G$ is the mapping (given the structure of the model) of the policy changes into results generated by the model. A solution $\hat{y}$ is a Point Estimate solution when the parameters $\theta$ are all set to their Point Estimates $\hat{\theta} ; i . e ., \hat{y}=G(X, \hat{\theta})$. If we are able to define a probability density function (pdf) over $\theta$, denoted $f(\theta)$, we can conduct a CSSA or USSA. In the case of a CSSA, for example, we obtain a Mean solution $\bar{y}$ by evaluating

$$
\bar{y}=\frac{1}{\sum_{i=1}^{S} f\left(\theta_{i}\right)}\left(\sum_{i=1}^{S} f\left(\theta_{i}\right) G\left(X, \theta_{i}\right)\right)
$$

where $S$ denotes the range of parameters to be evaluated.

Clearly $\bar{y}$ need not equal $\bar{y}$. Note also that $f(\theta)$ need not be diffuse. Intuitively one might expect that GE models are sensitive to certain perturbations of "key" parameters, such that it might not be hard to find "reasonable" parameter values to generate any desired result. We generally employ policy results in favor of outcomes that are (a priori) more likely.

If we denote the number of parameters subject to perturbation by $N_{p}$ and assume that we employ the same number of estimates $\left(N_{e}\right)$ for each such parameter, the number of solutions required by a CSSA is $N_{s}^{c}=\left[N_{p}\left(N_{e}-1\right)\right]+1$ and the number required by an USSA is $\mathrm{N}_{s}^{\mathrm{u}}=\mathrm{N}_{e}^{\mathrm{NP}}$. Table 1 presents several sobering numerical examples of the values of $\mathrm{N}_{S}^{\mathrm{C}}$ and $\mathrm{N}_{S}^{\mathrm{u}}$ implied by given values of $\mathrm{N}_{e}$ and $\mathrm{N}_{\mathrm{p}}$. Assuming that the perturbations of parameter estimates are 
TABLE 1

Hypothetical Number of Reguired Solutions

CONDITIONAL SENSITIVITY

ANALYSIS $\left(\mathrm{N}_{S}^{\mathrm{C}}\right)$

Number of Number of Parameters $\left(N_{p}\right)$
UNCONDITIONAL SENSITIVITY

ANALYSIS $\left(\mathrm{N}_{\mathrm{s}}^{\mathrm{u}}\right)$

Number of Parameters $\left(N_{p}\right)$

Estimates

$\left(\mathrm{N}_{\mathrm{e}}\right.$

$\begin{array}{llllllll}2 & 3 & 4 & 5 & 10 & 20 & 40 & 2\end{array}$

3

4

5

10

\begin{tabular}{rrrrrrrrrrrrrr}
\hline 3 & 5 & 7 & 9 & 11 & 21 & 41 & 81 & 9 & 27 & 81 & 243 & 59049 \\
5 & 9 & 13 & 17 & 21 & 41 & 81 & 161 & 25 & 125 & 625 & 3125 & 9765625 \\
7 & 13 & 19 & 25 & 31 & 61 & 121 & 241 & 49 & 343 & 2401 & 16807 & 282475250 \\
9 & 17 & 25 & 33 & 41 & 81 & 161 & 321 & 81 & 729 & 6561 & 59049 & $\ldots$ \\
11 & 21 & 31 & 41 & 51 & 101 & 201 & 401 & 121 & 1331 & 14641 & 161051 & $\ldots$ \\
13 & 25 & 37 & 49 & 61 & 121 & 241 & 481 & 169 & 2197 & 28561 & 371293 & $\ldots$ \\
15 & 29 & 43 & 57 & 71 & 141 & 281 & 561 & 225 & 3375 & 50625 & 759375 & $\ldots$ \\
\hline
\end{tabular}

Note: A dash indicates a number in excess of one billion. 
symmetrical about the point estimate, $\mathbb{N}_{e}$ only takes on odd values. The computational burden implied by modest values of $\mathrm{N}_{e}$ and $\mathrm{N}_{p}$ is evidently quite severe for an USSA. By contrast, the computations involved in a CSSA appear quite reasonable. These judgements must be tempered by the importance of the policy impact at issue and the computational budget available. Nonetheless, it is obviously worthwhile considering ways to mitigate the burden of the USSA. One attractive alternative to a complete unconditional analysis is a semi-conditional analysis in which certain blocks of parameters are perturbed conditionally with respect to other blocks of parameters, but are perturbed unconditionally with respect to other parameters in the same block. Thus we might view the elasticities of factor substitution as one block, import elasticities as another block, and own-price demand elasticities as a third block. Given the point estimates in the second and third blocks, an unconditional analysis with respect to the various factor substitution elasticities could be undertaken. One then holds the values of the first and third blocks constant at their point estimate while unconditionally perturbing the various import elasticities. Finally, the demand elasticities are perturbed conditional on the first two blocks of parameters being held at their point estimates.

An obvious variant on semi-conditional analyses with respect to blocks of parameters is to identify certain parameters as "critical", in the sense that one expects the policy impacts to be particularly sensitive to their values. The literature abounds with examples of such parameters. Fullerton, Shoven and Whalley [1983] and Fullerton and Lyon [1983] emphasize the 
elasticity of savings with respect to the net rate of return, Fullerton [1982] focuses on the aggregate labour supply elasticity, Whalley [1980] and Brown and Whalley [1980] indicate clearly the importance of assumed import elasticities, and Harris [1985] emphasizes a certain weighting parameter on his alternative pricing hypotheses. The great danger of such approaches, however, is the "ad hoc" nature of the choice of parameters to be studied, as is widely recognized. Moreover, any given parameter may be critical in one model for one set of policy simulations and yet be relatively unimportant in another model for different policies: compare Fullerton [1982] and Piggott and whalley [1984; Ch. 10] with regard to the labour supply elasticity. Nonetheless, it would be foolish to abrogate the use of conmon sense and intuition in trying to isolate the most important parameters, even when combinations of parameter perturbations are considered.

One major implication of the computational burden of systematic sensitivity analyses, however "conditional" they are, is a renewal of interest in algorithmic speed. ${ }^{8}$ In Kimbell and Harrison [1984] [1986] we introduced two new algorithms that allow one to rapidly solve a rich class of applied GE models. The first algorithm is the Analytic Factor Price Solution (AFPS) for any CES class of GE models that allows: (i) any number of factors and goods; (ii) any pattern for distribution parameters in the single-level CES production functions or (single) utility function; (iii) any pattern of efficiency parameters in the production function; and (iv) any arbitrary pattern of factor taxes across factors and producing sectors. The AFPS does not apply to the CES class that includes: (i) more than one private household; (ii) any interindustry (input-output) flows; (iii) elasticities of substitution in production that vary from sector to sector; (iv) an elasticity of substitution in consumption different from the (uniform) elasticity of 
substitution in production; and ( $v$ ) government factor demands that are not proportional to aggregate private industry factor demands. The AFPS is an exact, algebraic, closed-form solution for the GE values of all endogenous variables (i.e., the reduced form of any. structural GE model in the CES class defined above). No iterations whatsoever are required to solve GE models for which the AFPS applies. We use the speed of the AFPS in Appendix $c$ to undertake an exhaustive USSA of a simple GE model. This exercise allows us to evaluate the possible dangers of using a CSSA rather than an USSA.

The AFPS motivates the second algorithm, a simple iterative Factor Price Revision Rule (FPRR) for a wider class of popular numerical GE models that do not appear to have a closed-form solution. The. FPRR has proven to be a rapid and efficient solution algorithm for many large-scale GE models, including the GEMTAP model of the U.S. economy (see Ballard, Shoven and Whalley [1985]) and the global trade model presented in Harrison [1985a]. In Harrison [1985], Harrison and Kimbel1 [1985], and Harrison and Rutstrom [1986] a CSSA of each policy simulation is presented. Five alternative values for each of 720 parameters are considered, requiring 2881 solutions for each policy experiment. The FPRR made such large sensitivity analyses computationally feasible.

\subsection{Reporting Results}

Assuming that we have been able to construct prior pof's for the parameter estimates of interest, and that we are able to compute a large number of solutions to the model in question, how are we to report the results of a large sensitivity analysis in a useful way? As noted earlier, two steps 
can dramatically reduce the dimensionality of the reporting problem. The first is to focus on a subset of the endogenous variables of the model; for example, Harrison [1985] only reports a measure of aggregate welfare change due to each policy. The second step is to report several descriptive statistics about the distribution of solution values for those endogenous variables; for example, Harrison [1985] reports the mean and standard deviation of the distribution. In this section we examine certain aspects of this second step, especially the question of making explicit the weighting scheme adopted for any sensitivity analysis.

Assume that we are concerned with the sensitivity of a model to different estimates for two parameters, $\beta_{1}$ and $\beta_{2}$. The model may have many more parameters than just these two, in which case the sensitivity results are of course conditional on the estimates used for the other parameters. To simplify matters, assume in Case A that the prior pdf of the second parameter estimate $\left(\beta_{2}\right)$ is discrete and consists of three values: the point estimate with probability 0.5 , one other estimate with probability 0.4 , and a final estimate with probability 0.1 . We also assume that the prior pdf of the first parameter estimate $\left(\beta_{1}\right)$ is discrete; but in this case it is uniform and takes on only two values each with equal probability.

A complete enumeration of all possible simulations in Case $A$ is presented in Table 2. In simulation 1 the two point estimates are adopted, each with a marginal probability of 0.5 . Assuming independence of the random variables $\beta_{1}$ and $\beta_{2}$, we may calculate their joint probability as the product of their marginal probabilities. This is shown in column 4 for case A. Simulation 2 holds constant the value of $\beta_{1}$ and adopts the second value of $\beta_{2}$, 


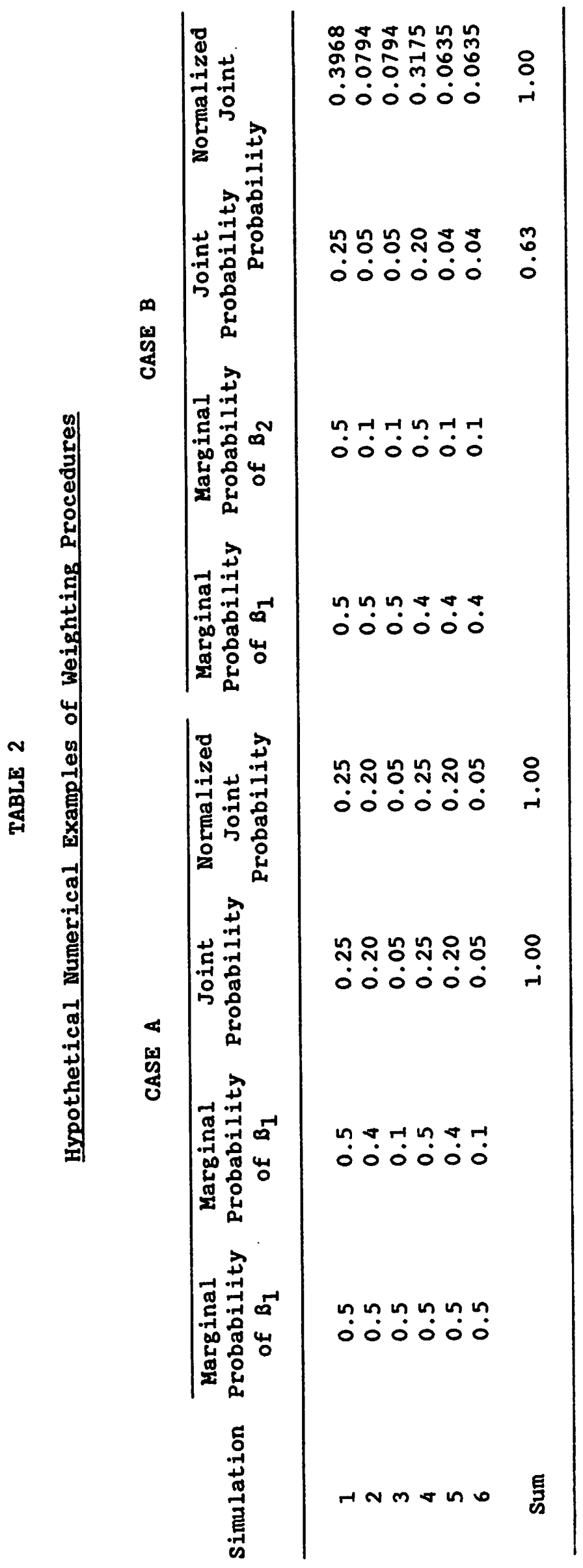


with resulting joint probability 0.2 ; similarly, simulation 3 adopts the final value of $\beta_{2}$, which has the lowest marginal probability of the three values considered. Simulations 4,5 and 6 repeat the sequence of $\beta_{2}$ values with the second value of $\beta_{1}$ (which also has marginal probability 0.5 ). By the laws of probability, and the knowledge that we have completely enumerated the joint distribution of the two parameters, we note that the sum of the joint probabilities is one. Thus we do not need to "normalize" the joint probability values, and simply repeat the column 4 values in column 5 .

In Case B we consider a more likely situation in which complete enumeration of the pdf of one or more of the parameters is not possible, presumably because it would be too expensive computationally even if possible. Two interpretations of this case are valid. The first is to think of the prior pdf of $\beta_{1}$ as having three or more discrete values, only two of which are considered (having marginal probabilities that sum to only 0.9 ), and the prior pdf for $\beta_{2}$ as having four or more discrete values, only three of which are considered (having marginal probabilities that sum to only 0.6 ). The second interpretation is that we are only evaluating discrete approximations to the continuous prior pdf of each parameter. This latter interpretation is in practice the most likely; in most cases we are able to assume that the prior pdf for each parameter is either rectangular and uniform over a finite interval or Gaussian.

Irrespective of the interpretation, we note from Table 2 that the joint probabilities of the six simulations for Case B do not sum to one. Thus we normalize (by the constant of proportionality $1.5873015=1 / 0.63$ ) so that the joint distribution is proper. Alternatively, we could have normalized each of the two marginal distributions. 
In Case $A$ and Case B, the normalized joint probabilities for each simulation provide the weights used when reporting the results of the simulations. Assume that the endogenous variable we are concerned with is the percentage change in employment in a certain sector from the benchmark equilibrium as the result of some tariff change. Hypothetical values are listed in Table 3 for each simulation. For pedagogic purposes assume that the same employment impacts obtained in Case A as in Case B. The weighted average percent change in employment is zero in Case A and 0.1111 in Case B. Note that other descriptive statistics could be computed once we know the pdf of the employment changes. The comparison of Cases $A$ and $B$ also illustrates the obvious point that the pdf of employment changes is sensitive to the weights attached to given parameter values by the prior pdf.

Several descriptive statistics may be of interest once the pdf for an endogenous variable has been generated. The first two moments, the mean and variance, provide familiar measures of central tendency and dispersion about the mean. Note that there is, in general, no presumption that the pdf for any endogenous variable is Gaussian; one should not therefore assume that the mean and standard deviation are in any way "sufficient statistics" of that distribution. The probability of a positive or negative value for the variable may be obtained by numerically evaluating the pdf over the relevant range of values. This provides a useful measure of the confidence one can attach to qualitative inferences in the numerical GE model, due account being explicitly made of the weight and uncertainty of the data used to calibrate the model. 
TABLE 3

Weighting Procedure Applied to Hypothetical Simulation Results

\begin{tabular}{cccccrr} 
& & \multicolumn{2}{c}{ CASE A } & & \multicolumn{2}{c}{ CASE B } \\
\cline { 3 - 4 } \cline { 5 - 6 } Simulation & $\begin{array}{c}\text { Percent } \\
\text { Change in } \\
\text { Employment }\end{array}$ & $\begin{array}{c}\text { Normalized } \\
\text { Joint } \\
\text { Probability }\end{array}$ & $\begin{array}{c}\text { Weighted } \\
\text { Employment } \\
\text { Change }\end{array}$ & $\begin{array}{c}\text { Normalized } \\
\text { Joint } \\
\text { Probability }\end{array}$ & $\begin{array}{c}\text { Weighted } \\
\text { Employment } \\
\text { Change }\end{array}$ \\
\hline & 1.00 & 0.25 & 0.25 & & 0.3968 & 0.3968 \\
1 & 1.00 & 0.20 & 0.20 & & 0.0794 & 0.0794 \\
3 & 1.00 & 0.05 & 0.05 & & 0.0794 & 0.0794 \\
4 & -1.00 & 0.25 & -0.25 & & 0.3175 & -0.3175 \\
5 & -1.00 & 0.20 & -0.20 & & 0.0635 & 0.0635 \\
6 & -1.00 & 0.05 & -0.05 & & 0.0635 & -0.0635 \\
SUM & & 1.00 & 0.0 & & 1.00 & 0.1111 \\
\hline
\end{tabular}




\section{APPLICATIONS}

\section{1 "Are Developed Country Multilateral Tariff Reductions Necessarily}

Beneficial to the U.S.?"

Whalley and Wigle [1983] employ the seven-region global GE model of

a multilateral tariff reduction by developed countries. They show that the

U.S. loses from such policies, contrary to comparable findings of cline,

Kawanambe, Kronsjo and Williams [1978], Baldwin, Mutti and Richardson [1980],

Brown and Whalley [1980] and Deardorff and Stern [1981]. 9 More significantly,

their result is contrary to one of the implicit tenets of U.S. trade policy:

Since the early 1930s, U.S. commercial policy has been dominated by a belief both in the desirability of free trade and the need to achieve that end through multilateral reductions in trade barriers. It was the U.S. that initiated bilateral negotiations to reduce protection in 1930s, the U.S. that was the main driving force behind the setting up of the GATT in the late 1940s, and the U.S. that initiated the ensuing rounds of GATT negotiations. In spite of the growing frictions in recent years, the basic belief that multilateral trade liberalization is good for the U.S. appears to have remained unshaken as one of the tenets of foreign trade policy. While the results presented in this paper may be viewed as close to heretical in policy circles, their message is abundantly clear. Further participation in multilateral tariff reductions under a GATT framework of equal proportional reductions of tariffs on manufactures may not be in the U.S. national interest. (Whalley and Wigle [1983; p. 66/7]).

In this section we evaluate the robustness of this important policy result.

It is infeasible to consider all of the parameters in the model. 10

Three classes of elasticities will be considered for sensitivity analysis:

(i) Elasticities of substitution between import types - these import elasticities are the same for all commodities in a given bloc. This elasticity is referred to as SIG and differs by bloc. It is calibrated to an estimate of the price elasticity of demand for exports. 
(ii) The common elasticity of substitution between imports and domestic production. This value is assumed to be the same for all blocs and all commodities and is referred to as SIGI. As specified, all blocs are assumed to face the same export price elasticity. This export price elasticity is used to calibrate SIGI.

(iii) The elasticity of substitution between capital and labour, referred to as SUB. SUB is the same in a given industry in all blocs; there are six industries in each bloc.

Table 4 presents a series of estimates of import (own) price elasticities, import income elasticities, and export (own) price elasticities gleaned from an exhausting, if not entirely exhaustive, literature survey reported in Appendix A (available on request). We also undertook an econometric reestimation of the CES elasticities of substitution for each sector. The results are reported in Appendix B (available on request), and led us to adopt elasticity PE (SE) values of $0.9450(0.0407), 0.4256(0.1050), 0.2930$ $(0.1016), 0.9387(0.1084),(1.1182)(0.0751)$ and $1.9885(0.4769)$ in the six sectors of the Whalley model. ${ }^{11}$ These new estimates are designed to provide more representative Point Estimates (PE) than those adopted by Whalley [1984], as well as a Standard Error (SE) for use in our sensitivity analyses. We presume throughout that the pdf for each parameter is univariate normal and that our PE and SE are "large-sample" estimates.

Table 5 indicates the importance of the choice of these elasticities for Welfare in each region (measured by the Hicksian equivalent variation in billions of 1977 U.S. dollars). Each elasticity is perturbed four times from it's PE value, at values \pm 0.7 and \pm 1.4 times the $S E$. Use of the SE for each elasticity provides a natural metric as to what are "reasonable" perturbations. The column of Whalley Point Estimate results uses the original elasticity $\mathrm{PE}$, and the remaining columns employ the estimates from Table 4 . 
TABLE 4

\section{Literature Survey of Trade Elasticities}

Import Price Elasticities Import Income Elasticities Export Price Elasticities Region

$\frac{\text { Literature }}{\mathrm{PE}} \quad \frac{\text { Whalley }}{\mathrm{SE}} \quad \frac{\text { Literature }}{\mathrm{PE}} \quad \frac{\text { Whalley }}{\mathrm{SE}}$

Literature PE SE
Whalley PE

\begin{tabular}{|c|c|c|c|c|c|c|c|c|c|c|}
\hline 1. & EEC & -1.1090 & .3504 & -0.91 & 1.8112 & .1992 & 1.77 & -1.2584 & .3304 & -1.14 \\
\hline 2. & U.S. & -1.4132 & .3412 & -1.66 & 1.51 & .1249 & 1.51 & -1.2931 & .3580 & -1.41 \\
\hline 3. & Japan & -1.0241 & .3216 & -0.78 & 1.23 & .0942 & 1.23 & -1.3367 & .4614 & -1.25 \\
\hline 4. & Canada & -1.1943 & .3633 & -1.02 & 1.20 & .0736 & 1.41 & -0.9052 & .2473 & -1.26 \\
\hline 5. & $O D C$ & -0.9000 & .5115 & -1.02 & 1.4125 & .2240 & 1.41 & -0.8798 & .3588 & -1.26 \\
\hline 6 . & OPEC & -0.8970 & .3833 & -0.89 & 0.3795 & .1591 & 0.24 & -1.17 & NA & -0.83 \\
\hline 7. & NIC & -1.3654 & .7892 & -1.38 & 0.3047 & .2396 & 1.29 & -0.5272 & .2172 & -1.41 \\
\hline 8. & LDC & -1.4708 & .7176 & -1.28 & 0.8991 & .2442 & 1.43 & -0.6620 & .1964 & -1.82 \\
\hline Av & $\begin{array}{l}\text { ated } \\
\text { age }\end{array}$ & -1.1601 & .4524 & -1.303 & 1.2554 & .1797 & 1.3736 & -1.0816 & .3256 & -1.2398 \\
\hline
\end{tabular}

Source: Appendix A. NIC and LDC refer to Newly Industrialized Countries and Less Developed Countries, respectively. 
TABLE 5

Conditional Systematic Sensitivity Analysis of Welfare Impact of Multilateral Tariff Reduction in the Whalley Model

\begin{tabular}{clcccccc}
$\begin{array}{c}\text { Whalley } \\
\text { Point } \\
\text { Estimate }\end{array}$ & Region & $\begin{array}{c}\text { Point } \\
\text { Estimate }\end{array}$ & Mean & $\begin{array}{c}\text { Standard } \\
\text { Error }\end{array}$ & $\begin{array}{c}\text { Minimum } \\
\text { Value }\end{array}$ & $\begin{array}{c}\text { Maximum } \\
\text { Value }\end{array}$ & $\begin{array}{c}\text { Probability } \\
\text { of Gain }\end{array}$ \\
\hline 0.66 & EEC & -0.21 & -0.23 & 0.43 & -2.88 & 1.35 & 0.09 \\
-1.07 & US & -0.99 & -1.00 & 0.16 & -1.96 & -0.44 & 0.00 \\
0.83 & JAPAN & 0.84 & 0.83 & 0.10 & 0.15 & 1.08 & 1.00 \\
0.63 & OTHER DEVELOPED & 1.06 & 1.10 & 0.61 & 0.48 & 5.50 & 0.98 \\
0.18 & OPEC & 0.23 & 0.22 & 0.05 & -0.22 & 0.30 & 0.99 \\
0.21 & NIC & 0.26 & 0.25 & 0.09 & -0.16 & 0.57 & 0.98 \\
-0.16 & LDC & 0.26 & 0.25 & 0.09 & -0.16 & 0.57 & 0.98 \\
1.30 & WORLD & 1.69 & 1.67 & 0.13 & 0.99 & 1.97 & 1.00 \\
\hline
\end{tabular}

Note: Welfare is evaluated as the Hicksian equivalent variation in billions of $1977 \mathrm{U} . \mathrm{S}$. dollars. 
Note that by simply revising the PE values one obtains a qualitatively different welfare impact for the EEC and LDC regions. The mean results correspond closely with the PE results for all regions.

The minimum and maximum welfare impacts on the EEC, Other Developed, OPEC and LDC regions all straddle the origins. In other words, there exist parameter values for the elasticities considered that can make the impact on welfare in these regions positive or negative. The key question, however, is whether or not these parameter values are "reasonable" in the sense of being "a priori" likely. The final column reports the probability that the welfare impact is positive. In all regions we are able to draw strong qualitative conclusions, even when there exist parameter values that imply a different sign. Thus our use of a non-diffuse prior pdf on the elasticity has nontrivial implications for the interpretation of these results.

The U.S. welfare impact in Table 5 is consistent with the findings of Whalley and Wigle [1983]. For the parameter range considered here the U.S. always "loses". We now consider the further robustness of these results when we undertake an USSA.

The relative "importance" of elasticities to the results of numerical GE modelling depends on both the type of results which are of primary interest and the policy experiment considered. Two suggested indicators of the sensitivity of U.S. welfare to different elasticities could be used. The difference between $U . S$. Welfare when the elasticity is at +1.4 standard errors and when it is at -1.4 standard errors in the CSSA, denoted $\delta$, is used here as the referred index of elasticity sensitivity of results. The measure 
$\delta$, shown in Table 6 , is used to rank the elasticities in terms of their effect on U.S. welfare, since it takes account of the imprecision of our estimates as well as the direct impact of a given unit change of the elasticities.

U.S. welfare is affected most by changes in its own import price elasticity and the import price elasticities of the major trading partners of the U.S., especially the other Developed Countries bloc. The common export elasticity is also very important. The non-traded sector elasticity of capital-for-labour substitution is the most important of the SUB values, but it's absolute contribution is quite small compared to the trade elasticities. This may result from the special structure of the model which has a common value for suB in all blocs in a given industry.

Based on these rankings, an USSA was conducted for the multilateral tariff reduction. The elasticities varied were the import price elasticities for the U.S. and the Other Developed bloc, and the common export elasticity. These USSA results are presented in Table 7. The welfare effects for several blocs straddle the origin in the USSA. The EEC, U.S., the OD bloc and the LDC bloc all fall into this category. In every case except the EEC, the bulk of the "posterior" pdf of welfare impacts lies on one side of the origin. The EEC has a $38 \%$ chance of experiencing a welfare gain from this policy, with the uncertainty in this conclusion deriving from the uncertainty about our elasticity estimates.

It is interesting to note from Table 7 that the U.S. can gain from the multilateral tariff reduction: there exist parameter values such that the welfare gain is positive. However, when we further enquire into the "reasonableness" of those parameter values, we conclude that they do not 
TABLE 6

Importance of Elasticities to U.S. Welfare for

Multilateral Tariff Reduction Policy

Elasticity (Region or Industry)

$\delta \quad$ Rank

\begin{tabular}{|c|c|c|}
\hline SIG & (E.E.C.) & .306 \\
\hline SIG & (U.S.) & 1.000 \\
\hline SIG & (Japan) & .182 \\
\hline SIG & (0. Dev.) & 1.297 \\
\hline SIG & (O.P.E.C.) & .013 \\
\hline & (N.I.C.) & .049 \\
\hline & (L.D.C.) & .12 \\
\hline SIGI & (Al1 regions) & .316 \\
\hline SUB & $(\mathrm{Ag} \cdot \&$ Food $)$ & .001 \\
\hline SUB & (Mining) & .001 \\
\hline SUB & (Energy) & N.A. \\
\hline SUB & (HI) & .001 \\
\hline & (M2) & .002 \\
\hline & (non-traded) & .014 \\
\hline
\end{tabular}

Notes: Ml refers to Non-Mechanical Manufacturing, and

M2 refers to Equipment and Vehicles Manufacturing.

Note that the model could not be solved, for reasonable computational expense, for the smallest value of this elasticity $(0.15)$. Changes in this elasticity within the limits where it did solve led to welfare changes for the U.S. comparable to those for the higher values of the elasticity. 
TABLE 7

Unconditional Systematic Sensitivity Analysis of Welfare Impact

of Multilateral Tariff Reduction in the Whalley Model

\begin{tabular}{|c|c|c|c|}
\hline $\begin{array}{l}\text { Point } \\
\text { Estimate }\end{array}$ & . & $\begin{array}{l}\text { Standard } \\
\text { Error }\end{array}$ & $\begin{array}{l}\text { Minimum } \\
\text { Value }\end{array}$ \\
\hline
\end{tabular}

$\begin{array}{lrrrrrr}\text { E.E.C. } & -.21 & -.40 & 1.28 & -3.86 & 2.58 & .38 \\ \text { U.S. } & -.99 & -1.06 & .50 & -2.36 & .32 & .02 \\ \text { Japan } & .84 & .76 & .28 & .01 & 1.30 & 1.00 \\ \text { O. Dev. } & 1.06 & 1.43 & 1.82 & -1.75 & 6.61 & .78 \\ \text { O.P.E.C. } & .23 & .16 & .15 & -.31 & .33 & .89 \\ \text { N.I.C. } & .50 & .45 & .14 & .04 & .82 & 1.00 \\ \text { L.D.C. } & .26 & .20 & .20 & -.35 & .61 & .85\end{array}$

$\begin{array}{lllllll}\text { HORLD } & 1.69 & 1.55 & .33 & .59 & 2.23 & 1.00\end{array}$


receive sufficient weight to alter the earlier inference: the chance of a welfare improvement for the U.S. is only $2 \%$.

The fact that the USSA generates wider bounds for the U.S. is not surprising since all of the solutions from the CSSA which involved the important elasticities are included in the USSA. Note that the bounds for all blocs' welfare need not be wider in the USSA than the CSSA since the elasticities were chosen for inclusion in the USSA on the basis of their impact on U.S. welfare. The extreme bounds of U.S. welfare do correspond to extreme values of the elasticities.

Reviewing the range of solutions underlying Table 7, three "rules of thumb" appear to emerge from the systematic sensitivity analysis relevant to the welfare effects. First, the more elastic the bloc's demand for imports, the larger their losses (or the smaller their gains). Secondly, the more elastic are your trading partner's demands for imports, the smaller the losses (or the larger the gains). Finally, the larger the (common) elasticity of demand for exports, the larger the gains to be shared from trade liberalization. 12

Systematic sensitivity analysis of a multilateral tariff reduction by the developed blocs therefore suggests that while some of the qualitative welfare effects are quite sensitive to elasticity specification, an important result does not appear to be in this class. In particular, the observation that the U.S. would lose from such a tariff cut is reinforced by the results. It was also found that an USSA conducted on a subset of results can generate a more diffuse pdf on welfare. In other words, USSA procedures on relatively few elasticities may be a worthwhile supplement to CSSA procedures 
on all elasticities of interest. This illustrated in Figure 1, where histograms for the CSSA on 14 elasticities and the USSA on 3 elasticities are compared.

\subsection{Comparison With Limited Sensitivity Analyses}

To the extent that sensitivity analyses have been reported in the literature ${ }^{13}$ they are limited. One example is the analysis of a unilateral $50 \%$ tariff reduction by the U.S. reported by whalley [1986]. In this section we compare his analysis with the results of an USSA of his model.

Whalley [1985b] reports nine simulations in all, including the counterfactual simulation with all parameters set to their PE. Two of these vary the elasticity of substitution between import types from a base value of 1.5 for all regions to 3.0 and 5.0 ; three simulations vary the import price elasticities that differ by region in the base case to a common value for all regions of $0.75,1.5$ and 3.0 ; the final three simulations vary the unitary import income elasticity common to all regions in the base case to 1.5 in all regions, to $0.9(1.1)$ and to 0.75 (1.25) in Developed (Non-Developed)

regions. None of these perturbations reflect any formal metric of uncertainty in the underlying estimates (e.g., one standard deviation).

In Table 8 we report a comparison of Whalley's sensitivity analysis and an USSA of the same policy simulation. This comparison is slightly forced in several respects. First and foremost, the models used in the two analyses are slightly different. Whalley [1985b] employs an eight-region version of his model in which Canada is separated from the Other Developed bloc, and we employ the seven-region model presented in Whalley [1984] [1985a]. Moreover, 
FIGURE I: Histograms of U.S. Welfare From Conditional and Unconditional Sensitivity (50\% Unilateral Tariff Cut by U.S.)

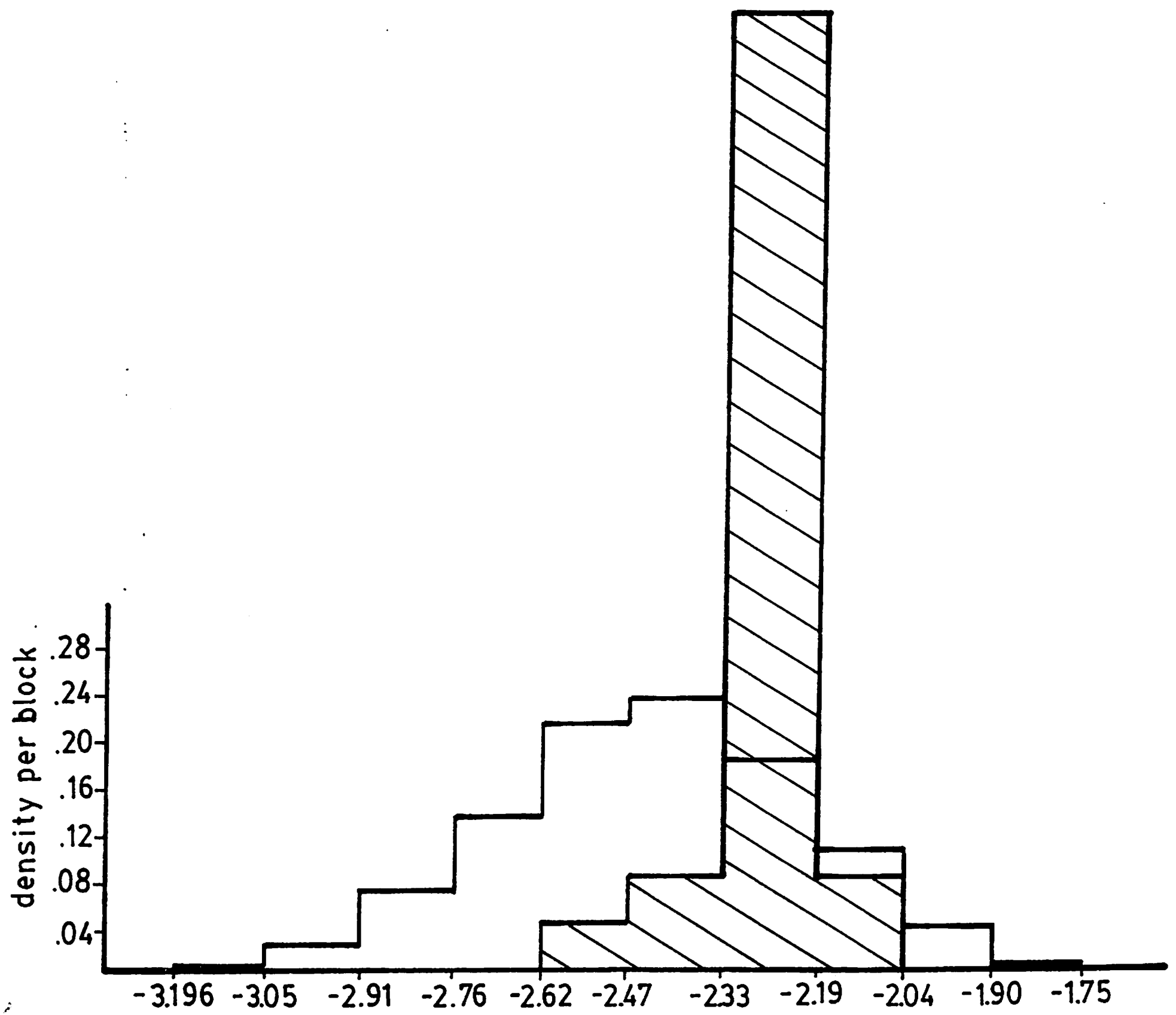

$\triangle$ CONDITIONAL HISTOGRAM

$\square$ UNCONDITIONAL HISTOGRAM 


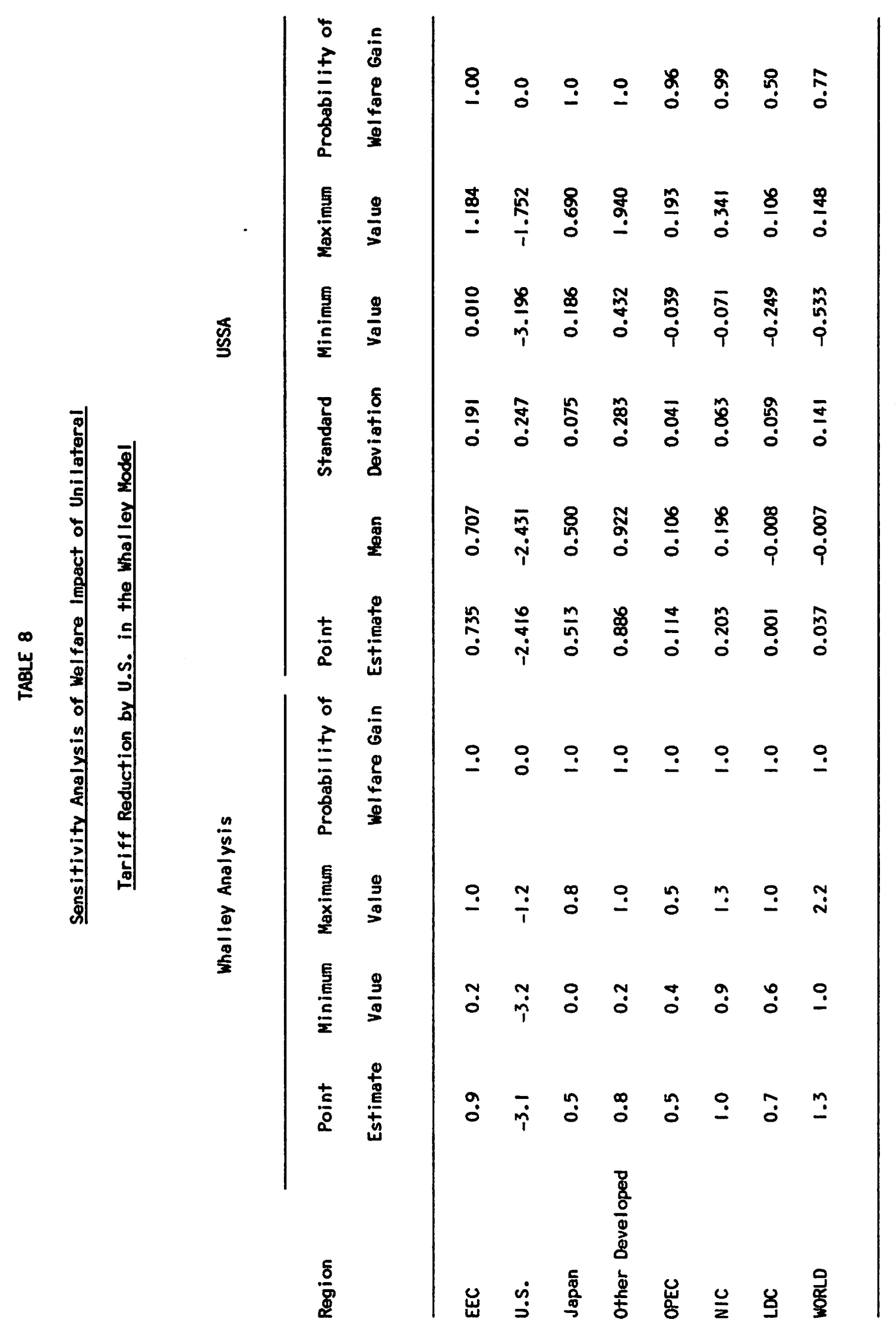


we employ our more exhaustive literature survey for certain key elasticities of the Whalley model, especially the import price elasticities. This results in some differences in the Point Estimate welfare impacts reported. ${ }^{14}$ Secondly, the Minimum and Maximum Values reported in Table 8 for the "Whalley Analysis" are drawn solely from the nine simulations reported by Whalley [1985b]. Similarly, the Probability of Welfare Gain is "computed" as if each of these nine simulations received equal a priori weight. In this case these weights are immaterial, as the sign of each region's welfare impact is identical in all nine simulations.

The USSA in Table 8 is undertaken by varying just three elasticities: the export price elasticity common to all regions, and the import price elasticities for the U.S. and other Developed regions. These elasticities were chosen on the basis of a CSSA of the same policy change that indicated that they had the most influence on the U.S. welfare result, using the methodology of the previous subsection. Our USSA involves 125 simulations. Table 8 indicates that the SSA results for the U.S. and Japan are more robust than suggested by Whalley's analysis, whereas the results for all other regions are less robust. In particular, it is possible to find values (all within 1.4 standard deviations of their PE) for just three elasticities such as to obtain qualitatively different welfare impacts for the OPEC, NIC and LDC regions and the World. The confidence of welfare gain in the LDC and the World drop significantly when one undertakes even a modest SSA. On the other hand, the results are suggestive of a more general message: that seemingly large scalar variations in sets of elasticities can engender over-confidence in the robustness of a model. 


\subsection{Trade Liberalization and Industrial Organization}

Harris [1985] explicitly acknowledges the sensitivity of his model to certain key parameters, in particular the weight [denoted ESH] given to the Eastman-Stykolt Hypothesis concerning pricing behavior in non-competitive sectors. He reports the results for several endogenous variables of a conditional SSA with respect to a small number of parameters. We report an unconditional SSA of these results for two perturbations of each of four parameters: ESH, a scaling parameter for the export elasticities (XSCAL), a scaling parameter for the import elasticities (SIG), and a scaling parameter for the economies of scale estimates (NUM). The last three parameters are decreased and increased by a third, following Harris [1985b]. The pricing hypothesis parameter ESH is varied from the base value of 0.5 to 0.3 and 0.7 , providing small perturbations relative to those considered by Harris [1986]. A total of 81 simulations were undertaken.

Table 9 reports the results of the USSA with respect to "all" four parameters noted above, and compares those results to the sensitivity with respect to variations in only one parameter (ESH). In all cases the model results appear to be extremely sensitive to concurrent modest variations in several parameters. The major results of the model remain qualitatively robust, although $18.5 \%$ of the simulations indicate a decline in GNE.

The welfare impacts of the tariff reductions, however, attain minimum values that place them much closer to traditional models. Harrison and Rutstrom [1986], for example, report a mean welfare impact of $0.91 \%$ for Canada of a global (complete) liberalization of manufacturing trade protection (tariffs and NTB's). Harrison and Kimbell [1985] report that Canada would gain $1.96 \%$ in welfare from an across-the-board (complete) liberalization of NTB's: Whalley [1985b] also reports comparable welfare gains for Canada. 
TABLE 9

Sensitivity Analysis of Tariff Reductions in the Harris Model

Percentage changes in variables

Unilateral Reduction Multilateral Reduction

$\begin{array}{lccccccc}\text { Variable } & \begin{array}{c}\text { Parameter(s) } \\ \text { Changed }\end{array} & \begin{array}{c}\text { Minimum } \\ \text { Value }\end{array} & \begin{array}{c}\text { Point } \\ \text { Estimate }\end{array} & \begin{array}{c}\text { Maximum } \\ \text { Value }\end{array} & \begin{array}{c}\text { Minimum } \\ \text { Value }\end{array} & \begin{array}{c}\text { Point } \\ \text { Estimate }\end{array} & \begin{array}{c}\text { Maxmimum } \\ \text { Value }\end{array} \\ \text { Wage } & \text { ESH } & 2.84 & 4.24 & 6.30 & 6.99 & 9.64 & 13.71 \\ & \text { all } & 0.45 & 4.24 & 11.18 & 3.65 & 9.64 & 21.66 \\ \text { GNE } & \text { ESH } & 0.76 & 1.61 & 2.83 & 3.37 & 4.97 & 12.32 \\ & \text { all } & -0.69 & 1.61 & 6.15 & 1.28 & 4.97 & 12.32 \\ \text { Welfare } & \text { ESH } & 1.35 & 2.03 & 2.95 & 2.49 & 3.62 & 5.25 \\ & \text { all } & 0.71 & 2.03 & 4.77 & 1.52 & 3.62 & 8.11\end{array}$




\section{CONCLUDING RETARKS}

In many respects our approach to the question of the robustness of applied GE analysis, urging the undertaking of systematic sensitivity analyses, is no more than requesting that currently implicit and "ad hoc" processes be made explicit and more systematic. We firmly believe in the utility of applied GE analyses, but that the results of those analyses are inadequately reported. Roberts $[1975$; p. 466] puts this point well:

Leonard J. Savage often said, "do research for your enemies, not your friends." This injunction conveys a good state of mind for approaching the task of reporting: imagine an adversary skilled both in statistics and the tactics of a trial lawyer who has been given the widest latitude to cross-examine you on any aspect of your study. Then try to draft your report in such a way that his every question can be answered convincingly by a reference to the report itself. The aim is to make the conclusions of the analysis completely believable, not simply to go through the motions to achieve a report superficially like those typically produced in the field.

The sensitivity analysis that we propose should go a long way towards addressing some of the questions that an intelligent skeptic of applied GE analysis should be asking (e.g., see Browning [1987; p. 11].

Our procedure can be improved in three ways. First, it is possible to improve the quality of the joint distribution of parameter estimates used as a prior for a SSA by directly estimating econometrically the relevant covariance matrix using "system-wide" procedures. This can already be done for blocks of parameters used to calibrate demand elasticities. It may be that our assumption of zero covariances between parameter estimates leads one to overstate the uncertainty surrounding the GE model.

Second, there are various ways to reduce the number of solutions of the GE model required to approximate an USSA. Pagan and Shannon [1985a] [1985b] have employed linearization techniques to this end. Our preliminary experience with those techniques suggests that they work extremely well for 
"aggregative" endogenous variables (e.g., total welfare change) but rather poorly with "sectoral" endogenous variables (e.g., employment in sector 1). The familiar difficulty with linearization procedures is that one does not always know beforehand "how non-linear" the implicit mapping is. However, our preliminary results would lead us to recommend the use of these procedures as an adjunct to a CSSA, especially concerning aggregative endogenous variables. Alternative approximation procedures, not relying on linearization assumptions (which have a tortured doctrinal history in applied GE analysis), are proposed by De Jong [1978], Frank [1978] and Vinod and Harrison [1987]. These and other procedures are well worth further study.

Third, we do not intend to limit our attention to the uncertainty over elasticities and ignore other specification choices in applied GE models. As noted earlier, to the extent that the user can define a (proper) prior pdf over the model specifications at issue, then our procedure generalizes naturally and directly. We find it natural to calibrate priors over elasticities, but are well aware that GE models can be very sensitive to other model features.

The primary application of our proposed SSA procedures will be to evaluate the uncertainty of policy shocks, as illustrated in section 3 . Several other applications may be of interest.

Our procedures could be applied to reconsider the question posed directly by whalley [1975]: is GE analysis more or less reliable than partial equilibrium analysis? We would re-cast this question as a comparison of distributions of endogenous variables. When one takes explicit account of the uncertainty underlying each type of analysis, do they arrive at roughly ${ }^{15}$ the same answer? Browning [1987; p. 22], for example, argues cogently along 
these lines, comparing his partial equilibrium calculations of the marginal welfare cost of taxation in the U.S. with the numerical GE results of Ballard, Shoven and Whalley [1985]:

Other things the same, general-equilibrium results are to be preferred to partial-equilibrium results. Until it is shown that the general-equilibrium models provide significantly different and more accurate estimates (for the same parameter values), however, the partial-equilibrium approach has some advantages. First, it is easily understood, so it is less likely that critical assumptions will be obscured. The sensitivity of the results to the four key parameter values is quite apparent in this treatment, for example. Second, it is simple for other investigators to perform sensitivity analysis by modifying the assumptions regarding parameter values if such changes seem appropriate. Finally, on a more substantive matter, the results here seem to imply that arriving at a more precise estimate of marginal welfare cost may well depend more on empirical investigation that narrows the range of possible parameter values than on developing more rigorous models that yield slightly better estimates for given parameter values.

Our SSA procudures are arguably a panacea to these proper complaints against the use of numerical GE models.

In a similar vein, Fullerton, Henderson and Shoven [1984] examine the implications of aggregating over sectors in an applied GE model. To the extent that sectoral variations in tax or tariff rates are more important than the levels of those rates, such aggregation can lead to very different policy results. They illustrate that such differences can indeed occur in the U.S. model of Ballard, Fullerton, Shoven and whalley [1985]. A natural question to ask is whether these differences due to aggregation are "large" relative to the uncertainty inherent in the disaggregated model. If aggregation only induces a change in welfare, for example, that is less than one standard deviation from the mean, then it could be argued that aggregation is less of a source of uncertainty than the basic elasticities of the model. 
FOOTNOTES

${ }^{1}$ our remarks pertain directly to the class of models mentioned above. A variant on this class is the so-called "Johansen-like" model--see Dixon, Parmenter, Sutton, and vincent [1982] and Bergman [1985] for a complete review. The general thrust of our remarks below also apply to these numerical GE models: see Cook [1980; Chapter 4] and Pagan and Shannon [1985a] [1985b].

2 Apart from the references cited earlier, see Mansur and Whalley [1984], St.-Hilaire and Whalley [1983], Piggott and Whalley [1985], Fullerton, Shoven and Whalley [1978] and Ballard, Fullerton, Shoven and whalley [1985].

${ }^{3}$ In his paper two "...explicit characterizations of partial equilibrium analysis are developed and used to assess the impact of the removal of distortionary capital income taxation in the United Kingdom. The solutions are compared to those obtained using more complicated devices for the computation of competitive equilibria. The exercises are repeated for different parameterizations of the model. The partial equilibrium techniques perform somewhat erratically as approximate methods. This suggests that although there is a considerable gain in computational simplicity in the use of partial equilibrium analysis, the reliability of results using more satisfactory general equilibrium techniques is considerably increased." (p. 310; emphasis added).

We may wish to consider only variations in parameters that are common to both partial and general equilibrium approaches, since the typical numerical GE model contains a significantly larger number of parameter estimates.

5 For example, see Brown and Whalley [1980; Table 13], Dervis, De Melo and Robinson [1982; Chs. 8-13], Dixon, Parmenter and Rimmer [1982], Fullerton, King, Shoven and Whalley [1981; Tables 3-5], Hartigan and Tower [1982; Tables 1-5] and Whalley [1980; Table 6].

${ }^{6}$ Clearly this also depends on the research budget provided for the exercise. Note that Johansen-style methods are very attractive for this type of exercise, given their speed of solution. One interesting question is whether or not the linearization approximation errors in the (one-step) Johansen solution procedure are "small" relative to the uncertainty of solution values due to parameter uncertainty. It is possible that the former errors may appear to be "large" in some (ill-defined) absolute sense, but pale into significance when compared to the latter uncertainties. 
'But not always: of ten the specification that is reported is the result of an interpretive search in which one or more possible explanatory variables have been constrained (e.g., eliminated) using prior information that is not commicated. It is possible that such a search was in fact a simplification search with an implicit objective of (non-causally constrained) conditional prediction, but this is not typical in the relevant econometric literature. Moreover, the end result from the reader's perspective is a distorted summary of the sample evidence. See Leamer [1978; Chs. 5 and 6] for further discussion.

8 Engles [1979] examines a separate algorithmic issue: the connectedness of equilibrium paths between discrete parametric deformations of numerical $G B$ models. Arguably, this is only a substantive issue if multiple equilibria exist for certain parameter configurations; see Kehoe [1980] and Kehoe and Whalley [1985] on the question of multiple equilibria, and some evidence that is is merely a theoretical curiosem for the class of models.widely employed for policy purposes.

9 Whalley and Wigle [1983; p. 66] offer several explanations as to why these results from different models and simulations are so different. The first two studies do not capture terms of trade effects, and the latter two studies also have sizeable tariff reductions by non-developed countries. Note also that we follow Whalley and Wigle [1983] by assuming unitary income elasticities in all regions; the non-unitary PE values reported in Table 4 are used in all other simulations of the Whalley model reported here.

10 Whalley [1985a] [1985b] presents the detailed structure of the model, and some intuition as to which parameters he considers are likely to be the most important for simulations of this kind. We pursue that intuition in our choice of parameters for study.

${ }^{11}$ These sectors are Agriculture and Food, Mining, Energy, Non-Mechanical Manufacturing, Equipment and Vehicle Manufacturing, and Non-Traded Goods. Our econometric estimates employed post-war U.S. data for 29 industries at a two-digit level.

12 Recall that the common export elasticity is in fact the elasticity of substitution between domestic goods and the composite of imports. The biggest welfare loss for the U.S. from the USSA $(-2.36)$ is associated with the highest value of the U.S. import elasticity, the lowest value of the other Developed bloc import elasticity, and the lowest value of the common export elasticity. Conversely, for the largest welfare gain for the U.S. (0.32) these elasticities are at their lowest, highest and highest values, respectively. 
13 The exceptions are Harrison [1986], Harrison and Kimbell [1985], Harrison and Rutstrom [1986] and Pagan and Shannon [1985a] [1985b].

14 Employing the original PE used by whalley [1984] in the seven-region model we obtain welfare impacts of $0.742,-2.225,0.516,0.794,0.084,0.161$, 0.070 and 0.004 , which differ noticeably from the "Whalley Analysis" values reported in Table 8 for the last three regions and the World.

${ }^{15}$ To be more precise, we could employ non-parametric statistical procedures to determine if the two distributions were significantly different. Or, to see if the mean of one distribution was significantly different from the mean of the other.

\section{REFERENCES}

Baldwin, R.E., Mutti, J., and Richardson, D., "Welfare Effects on the United States of a Significant Multilateral Tariff Reduction", Journal of International Economics, v. 10, 1980, pp. 405/423.

Ballard, C.L.; Fullerton D.; Shoven, J.B.; and Whalley, J., Tax Policy Evaluation with a Numerical General Equilibrium Hodel (Chicago: University of Chicago Press, 1985).

Ballard, C.L.; Shoven; J.B.; and Whalley, J., "General Equilibrium Computations of the Marginal Welfare Costs of Taxes in the United States", American Economics Review, v. 75, March 1985, pp. 128/138.

Bergman, L., "Johansen Models: A Review", Unpublished Manuscript, Stockholm School of Economics, 1985.

Brown, F. and Whalley, J., "General Equilibrium Evaluations of TariffCutting Proposals in the Tokyo Round and Comparisons with More Extensive Liberalization of World Trade", Economic Journal, v. 90,1980 , PP. 838/866.

Browning, E.K., "On the Marginal Welfare Cost of Taxation", American Economic Review, v. 77, March 1987, pp. 11/23.

Cline, W.R., et. al., Trade Negotiations in the Tokyo Round: A Quantitative Assessment (Washington: Brookings Institution, 1978).

Cook, L.H., Validation of a Johnasen-Type Multisectoral Model: Norway, 19491961 Unpublished Ph.D. Dissertation, Monash University (Australia), 1980.

De Jongh, D.C.J., "Structural Parameter Sensitivity of the 'Limits to Growth' World Model", Applied Mathematical Modelling, v. 2, 1978, pp. 77/80.

Dervis, K.; De Melo, J.; and Robinson, S., General Equilibrium Models for Development Policy (Cambridge: Cambridge University Press, 1982). 
Dixon, P.B.; Parmenter, B.R.; and Rimmer, R.J., "The Sensitivity of ORANI Projections of the Short-Run Effects of Increases in Protection to Variations in the Values Adopted for Export Demand Elasticities", IMPACT Preliminary Working Paper No. OP-35, IMPACT Centre, University of Melbourne, 1982.

Dixon, P.B.; Parmenter, B.R.; Sutton, J.; and Vincent, D.P., ORANI: A Multisectoral Kodel of the Australian Economy (Amsterdam: North-Holland, 1982).

Engles, C.R., Economic Equilibrium Under Deformation of the Economy, Unpublished Ph.D. Dissertation, Department of Operations Research, Stanford University, January 1979.

Frank, P.M., Introduction to System Sensitivity Theory (New York: Academic Press, 1978).

Fullerton, D., "On the Possibility of an Inverse Relationship Between Tax Rates and Government Revenues", Journal of Public Economics, v. 19, 1982, pp. 3/22.

Fullerton, D.; Henderson, Y.K.; and Shoven, J.B., "A Comparison of Methodologies in Empirical Models of Taxation", in H.E. Scarf and J.B. Shoven (eds.) Applied General Equilibrium Analysis (New York: Cambridge University Press, 1984).

Fullerton, D.; King, A.T.; Shoven, J.B.; and Whalley, J., "Corporate Tax Integration in the United States: A General Equilibrium Approach", American Economic Review, v. 71, 1981, pp. 677/691.

Fullerton, D. and Lyon, A.B., "Uncertain Parameter Values and the Choice Among Policy Options", Discussion Paper \#42, Woodrow Wilson School of Public and International Affairs, Princeton University, April 1983.

Fullerton, D.; Shoven, J.B.; and Whalley, J., "General Equilibrium Analysis of U.S. Taxation Policy" in 1978 Compendium of Tax Research (Washington, D.C.: Office of Tax Analysis, Treasury Department, 1978).

Fullerton, D., Shoven, J.B. and Whalley, J., "Replacing the U.S. Income Tax With a Progressive Consumption Tax: A Sequenced General Equilibrium Approach", Journal of Public Economics, v. 20, 1983, pp. 3/23.

Harberger, A.C., "The Incidence of the Corporate Income Tax", Journal of Political Economy, v. 70, 1962, pp. 215/240.

Harberger, A.C., "Efficiency Effects of Taxes on Income from Capital" in M. Krzyzaniak (ed.) Effects of Corporation Income Tax (Detroit: Wayne State University Press, 1966). 
Harris, R., "Market Structure and Trade Liberalization: A General Equilibrium Assessment", in T.N. Srinivasan and J. Whalley (eds.), General Equilibrium Trade Policy Modelling (Cambridge: MIT Press, 1986).

Harrison, G.W., "A General Equilibrium Analysis of Tariff Reductions", in T.N. Srinivasan and J. Whalley (eds.), General Equilibrium Trade Policy Modelling (Cambridge: MIT Press, 1986).

Harrison, G.W.; and Kimbell, L.J., "Economic Interdependence in the Pacific Basin: A General Equilibrium Approach", in J. Piggott and J. Whalley (eds.) New Directions in Applied General Equilibrium Analysis (New York: Cambridge University Press, 1985).

Harrison, G.W.; and Rutstrom, E.E., "The Effect of Manufacturing Sector Protection in Australia and ASEAN: A General Equilibrium Analysis", in C. Findlay and R. Garnaut (eds.), The Political Economy of Manufacturing Protection: Experiences of ASEAN and Australia (Sydney: Allen \& Unwin, 1986).

Hartigan, J.C.; and Tower, E., "Trade Policy and the American Income Distribution", Review of Economics and Statistics, v. 64, 1982, pp. $261 / 270$.

Kehoe, T.J., "An Index Theorem for General Equilibrium Models with Production", Econometrica, v. 48, 1980, pp. 1211/1232.

Kehoe, T.J.; and Whalley, J., "Uniqueness of Equilibrium in a Large-Scale Numerical General Equilibrium Model", Journal of Public Economics, v. 28,1985, pp. $247 / 254$.

Kimbell, L.J.; and Harrison, G.W., "General Equilibrium Analysis of Regional Fiscal Incidence", in H.E. Scarf and J.B. Shoven (eds.) Applied General Equilibrium Analysis (New York: Cambridge University Press, 1984).

Kimbell, L.J.; and Harrison, G.W., "On the Solution of General Equilibrium Models", Economic Kodelling, v. 3, 1986, pp. 197-212.

Leamer, E.E., Specification Searches (New York: Wiley, 1978).

Leamer, E.E.; and Leonard, H., "Reporting the Fragility of Regression Estimates", Review of Economics and Statistics, v. 65, 1983, pp. 306/317.

Pagan, A.R.; and Shannon, J.H., "Sensitivity Analysis for Linearized Computable General Equilibrium Models", in J. Piggott and J. Whalley (eds.), New Developments in Applied General Equilibrium Analysis (New York: Cambridge University Press, 1985a). 
Pagan, A.R.; and Shannon, J.H., "How Reliable Are ORANI Conclusions"?, Discussion Paper No. 130, Centre for Economic Policy Research, Australian National University, September 1985b; forthcoming, Economic Record.

Piggott, J.; and Whalley, J., UK Tax Policy and Applied General Equilibrium Analysis (London: Cambridge University Press, 1985).

Roberts, H.V., "Reporting of Bayesian Studies", in S.E. Fienberg and A. Zellner (eds.), Studies in Bayesian Econometrics and Statistics (Amsterdam: North-Holland, 1975).

Scarf, H.E., "On the Computation of Equilibrium Prices" in Ten Economic Essays in the Tradition of Irving Fisher (New York: Wiley, 1967).

Scarf, H.E., in collaboration with $T$. Hansen, The Computation of Economic Equilibria (New Haven: Yale University Press, 1973).

Scarf, H.E. and Shoven, J.B. (eds.) Applied General Equilibrium Analysis (New York: Cambridge University Press, 1984).

Shoven, J.B., "The Incidence and Efficiency Effects of Taxes on Income from Capital", Journal of Political Economy, v. 84, 1976, pp. 1261/1281.

Shoven, J.B.; and Whalley, J., "A General Equilibrium Calculation of the Effects of Differential Taxation of Income from Capital in the U.S.," Journal of Public Economics, v. 1, 1972, pp. 281/321.

Shoven, J.B. and Whalley, J., "Applied General Equilibrium Models of Taxation and International Trade", Journal of Economic Literature, v. 22, 1984 , pp. 1007/1051.

St.-Hilaire, F. and Whalley, J., "A Microconsistent Equilibrium Data Set for Canada for Use in Tax Policy Analysis", Review of Income and Wealth, v. 29, 1983, pp. 175/204.

Stern, R.M.; Francis, J.; and Schumacher, B., Price Elasticities in International Trade: An Annotated Bibliography (London: Macmillan for the Trade Policy Research Centre, 1976).

Vinod, H.D., and Harrison, G.W., "Sensitivity of Numerical General Equilibrium Models: Maximum Entropy Latin Square Designs", Unpublished Kanuscript, Department of Economics, University of Western Ontario, 1987.

Whalley, J., "How Reliable Is Partial Equilibrium Analysis?", Review of Economics and Statistics, v. 57, 1975, pp. 299/310. 
Whalley, J., "The United Kingdom Tax System 1968-1970: Some Fixed Point Indications of its Economic Impact", Econometrica, v. 45, 1977, pp. $1837 / 1858$.

Whalley, J., "General Equilibrium Analysis of U.S.-EEC-Japanese Trade and Trade Distorting Policies", Economie Applique, v. 33, 1980a, pp. 191/230.

Whalley, J., "Discriminatory Features of Domestic Factor Tax Systems in a Goods Mobile-Factors Immobile Trade Model: An Empirical General Equilibrium Approach", Journal of Political Economy, v. 88, 1980b, pp. $1177 / 1202$.

Whalley, J., "An Evaluation of the Tokyo Round Trade Agreement Using General Equilibrium Computational Methods", Journal of Policy Modelling, v. 3, 1982, pp. 341/361.

Whalley, J., "The North-South Debate and the Terms of Trade: An Applied General Equilibrium Approach", Review of Bconomics and Statistics, v. 66, 1984, pp. 224-234.

Whalley, J., Trade Liberalization Among Major World Trading Areas: A General Equilibrium Approach (Boston: MIT Press, 1985a).

Whalley, J., "Impacts of a 50\% Tariff Reduction in an Eight-Region Global Trade Model", in T.N. Srinivasan and J. Whalley (eds.), General Equilibrium Trade Policy Modelling (Cambridge: MIT Press, 1985b).

Whalley, J. and Wigle, R., "Are Developed Country Multilateral Tariff Reductions Necessarily Beneficial for the U.S.?", Economics Letters, v. 12, 1983, pp. 61/67. 
APPENDIX A

\section{Literature Review of Trade Elasticities}

This Appendix provides the gory arithmetical detail supporting the summary estimates of trade elasticities presented in the text. The objective of this exercise is quite simple: to generate simple or weighted averages of the Point Estimates (PE) and, where available, Standard Errors (SE) of estimates of the relevant Import (Own) Price Elasticities, Import Income (or "Activity") Elasticities, and Export (Own) Price Elasticities. Although some selectivity has been exercised (only when. we found the econometric methodology to be transparently shabby and/or data sources unusually sordid), we only intend to reflect a consensus view. An excellent critical review, which appeared after our compilations were completed, is Goldstein and Khan [1983]. The primary application of our summary estimates is to conduct systematic sensitivity analysis of the general equilibrium model detailed in Whalley [1984]; in many respects this determined our geographic and commodity coverage.

\section{Import Price Elasticities}

\section{I.1 EEC}

Three sets of weighted averages are computed in Table A1: (a) using estimates from Houthakker and Magee [1969]; (b) using estimates from Goldstein and Khan [1976]; and (c) using simple averages of estimates for each EEC member-nation from various sources (1isted in Table A2). Various averages are shown, depending on the sign of the $\mathrm{PE}$ and/or the use of trade weights for each individual nation. The preferred summary statistic is the weighted average of the 1iterature estimates (set (c)), giving a PE of -1.1090 and a SE of 0.3504 . 


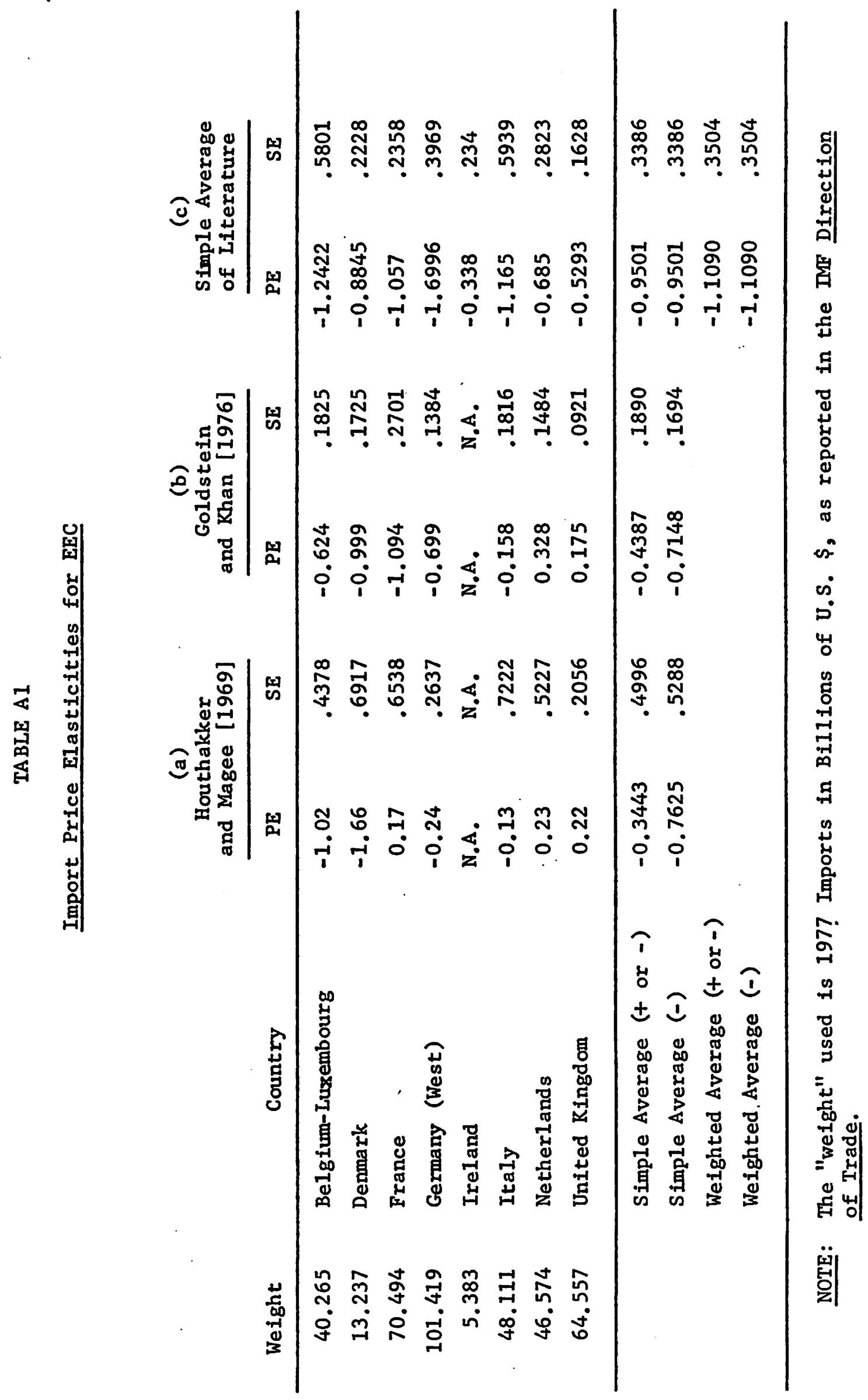




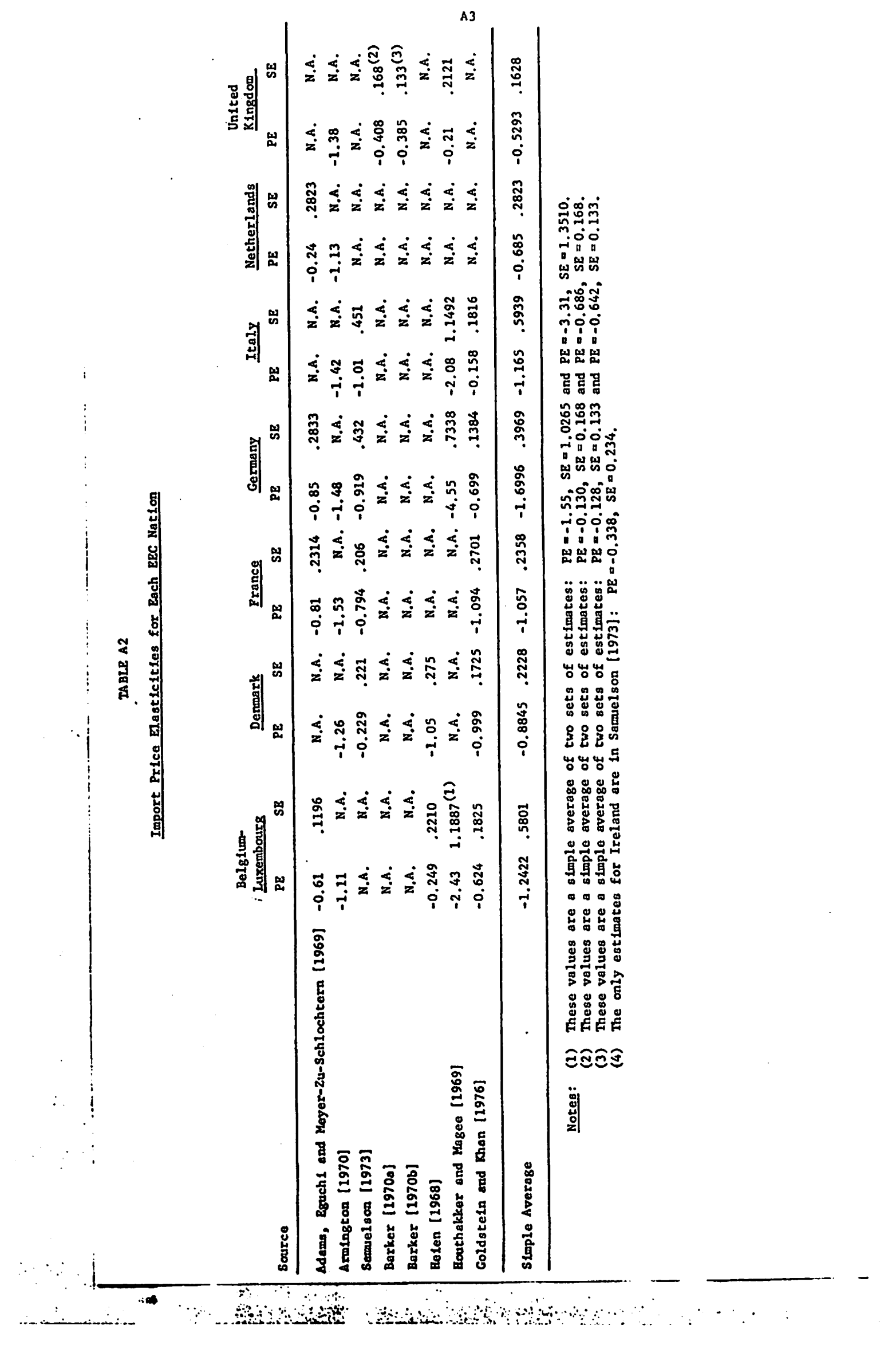




\section{I.2 U.S.}

Table A3 lists a series of estimates from the 1iterature. The : preferred summary statistic is the simple average of these estimates, giving a PE of -1.4132 and a SE of 0.3412 .

\section{I.3 Japan}

Table A4 1ists a series of estimates from the literature. The preferred summary statistic is the simple average of these estimates, giving a PE of -1.0241 and a SE of 0.3216 .

\section{I.4 Canada}

Table AS Iists a series of estimates from the literature (excluding Kohli [1982], unfortunately). The preferred summary statistic is the simple average of these estimates, giving a PE of -1.1943 and a SE of 0.3633 .

\section{I.5 Other Developed Countries (ODC)}

Table A6 lists a series of (readily available) estimates from the 1iterature for ODC excluding Canada. The preferred summary statistic is the simple average of these estimates, giving a PE of -0.89996 and a SE of 0.51146. If the estimates for Canada in Table A5 are pooled with those for ODC in Table A6, the overall simple average gives a PE of -0.9624 and a SE of 0.4818 .

\section{I.6 OPEC}

The only available estimate for an OPEC nation appears to be for Venezuela in Khan [1975], and gives a PE of -0.897 with a SE of 0.38333 .

\section{I.7 Newly Industrialized Countries (NIC)}

Table A7 1ists the estimates from the Iiterature (mainly Khan [1974]). 
TABLE A3

Import Price Elasticities for U.S.

\begin{tabular}{llc} 
Source & PE & SE \\
\hline 1. Adams, Eguch1 and Meyer-Zu-Schlochtern [1969] & -1.16 & .2829 \\
2. Armington [1970] & -1.73 & NA \\
3. Branson [1972; Table 12] & -1.46 & NA \\
4. Burgess [1974; Table 2, 1968 estimate] & -1.6209 & NA \\
5. Burgess [1975; Table 2A, 1968 estimate] & -1.6404 & NA \\
6. Burgess [1975; Table 2B, 1968 estimate] & -0.7314 & NA \\
7. Goldstein and Khan [1976] & -0.448 & .2274 \\
8. Houthakker and Magee [1969; Table 1] & -0.54 & .3396 \\
9. Houthakker and Magee [1969; Table 8] & -1.03 & .4239 \\
10. Joy and Stalen [1975] & -2.068 & .5199 \\
11. Kreinin [1967] & -1.107 & .155 \\
12. Leamer [1973; Table 4, Sample] & -2.3 & NA \\
13. Leamer [1973; Table 4, Posterior] & -2.5 & NA \\
14. Meyer-Zu-Schlochtern and Yajima [1970] & -1.88 & NA \\
15. Miller and Fratianni [1974; Table 2, & -0.365 & .1430 \\
16. Stern, Baum and Greene [1979] & -2.176 & .6381 \\
17. Stone [1979; Average I] & -1.63 & NA \\
18. Taplin [1973] & -1.05 & NA \\
\hline & -1.4132 & .3412 \\
\hline Simple Average & & \\
\hline
\end{tabular}


TABLE A4

Import Price Elasticities for Japan

\begin{tabular}{llc} 
Source & $\mathrm{PE}$ & $\mathrm{SE}$ \\
\hline 1. Armington [1970] & -1.47 & $\mathrm{NA}$ \\
2. Branson [1972; Table 12] & -0.93 & $\mathrm{NA}$ \\
3. Goldstein and Khan [1976; Table 6] & -1.229 & .3431 \\
4. Houthakker and Magee [1969; Table 1] & -0.72 & .30 \\
5. Meyer-Zu-Schlochtern and Yajima [1970] & -0.78 & $\mathrm{NA}$ \\
6. Stone [1979; Average I] & -1.23 & $\mathrm{NA}$ \\
7. Taplin [1973] & -0.81 & $\mathrm{NA}$ \\
\hline & -1.0241 & .3216 \\
\hline
\end{tabular}

TABLE A5

Import Price Elasticities for Canada

\begin{tabular}{|c|c|c|c|}
\hline & Source & $\mathrm{PE}$ & SE \\
\hline & Adams, Eguchi and Meyer-Zu-Schlochtern [1969] & -0.62 & .2952 \\
\hline 2. & Armington [1970] & -1.30 & NA \\
\hline 3. & Branson [1972; Table 12] & -0.61 & $\mathrm{NA}$ \\
\hline 4. & Houthakker and Magee [1969; Table 1] & -1.46 & .5468 \\
\hline 5. & Meyer-Zu-Schlochtern and Yamima [1970] & -1.49 & $\mathrm{NA}$ \\
\hline 6. & Samuelson [1973] & -1.29 & .2480 \\
\hline 7. & Taplin [1973] & -1.59 & \\
\hline & Simple Average & -1.1943 & .3633 \\
\hline
\end{tabular}


TABLE A6

Import Price Elasticities for Other Developed Countries

\begin{tabular}{|c|c|c|c|}
\hline Country & Source & $\mathrm{PE}$ & $S E$ \\
\hline \multirow[t]{3}{*}{ Australia } & Houthakker and Magee [1969; Table 8, total] & -0.21 & .1029 \\
\hline & $\begin{array}{c}\text { Houthakker and Magee }[1969 ; \text { Table } 8, \text { U.S. } \\
\text { imports] }\end{array}$ & -1.89 & 1.3404 \\
\hline & Samuelson [1973] & -0.416 & .3840 \\
\hline \multirow[t]{4}{*}{ Austria } & Armington [1970] & -1.32 & NA \\
\hline & Heien [1968] & -0.434 & NA \\
\hline & Samuelson [1973] & -1.42 & .4170 \\
\hline & Taplin [1973] & -0.39 & NA \\
\hline \multirow[t]{3}{*}{ Finland } & Samuelson [1973] & -0.184 & .122 \\
\hline & Taplin [1973] & -0.5 & NA \\
\hline & Goldstein and Khan [1976] & -0.319 & .1127 \\
\hline \multirow[t]{2}{*}{ Greece } & Sarantides [1972] & -2.10 & NA \\
\hline & Taplin [1973] & -1.47 & NA \\
\hline \multirow[t]{3}{*}{ Norway } & Armington [1970] & -1.19 & NA \\
\hline & Hou thakker and Magee [1969; Table 8] & -0.78 & .2229 \\
\hline & Taplin [1973] & -1.20 & NA \\
\hline Portugal & Taplin [1973] & -0.40 & NA \\
\hline \multirow[t]{2}{*}{ Spain } & Samuelson [1973] & -0.763 & .110 \\
\hline & Taplin [1973] & -1.55 & NA \\
\hline \multirow[t]{5}{*}{ Sweden } & Goldstein and Khan [1976] & -0.397 & .1654 \\
\hline & Armington [1970] & -1.30 & NA \\
\hline & Houthakker and Magee [1969; Table 1] & -0.79 & .7745 \\
\hline & Samuelson [1973] & -0.856 & .519 \\
\hline & Taplin [1973] & -0.23 & NA \\
\hline \multirow[t]{4}{*}{ Switzerland } & Armington [1970] & -1.35 & NA \\
\hline & Houthakker and Magee [1969; Table 1] & -0.84 & 1.8667 \\
\hline & Taplin [1973] & -1.10 & NA \\
\hline & Simple Average & -0.89996 & 0.51146 \\
\hline
\end{tabular}


TABLE A7

Import Price Elasticities for Newly Industrialized Countries

\begin{tabular}{llll} 
Source & Country & PE & SE \\
\hline Khan [1974] & Argentina & -0.850 & .7658 \\
& Brazil & -1.688 & .3069 \\
& Chile & -0.633 & .5652 \\
& Costa Rica & -1.982 & .8398 \\
& Ecuador & -1.173 & .3677 \\
& Turkey & -2.715 & 2.0568 \\
& Uruguay & -1.232 & .6222 \\
Taplin [1973] & Turkey & -0.65 & NA \\
& & & \\
& Simple Average & -1.3654 & .7892 \\
& Simple Average & -1.2597 & .5779 \\
& (excluding Khan's & & \\
& Turkey) & & \\
& & &
\end{tabular}

TABLE A8

Import Price Elasticities for Less Developed Countries

Source: Khan [1974]

\begin{tabular}{lcc} 
Country .. & PE & SE \\
\hline Colombia & -0.758 & .1792 \\
Ghana & -1.057 & 8.8083 \\
India & -2.188 & .6671 \\
Morocco & -0.981 & 1.2418 \\
Pakistan & -0.779 & .3727 \\
Peru & -1.785 & .9061 \\
Philippines & -2.731 & 1.4077 \\
Sri Lanka & -1.074 & .2486 \\
Simple Average & -1.4191 & 1.7289 \\
Simple Average (excluding Ghana) & -1.4708 & 0.7176 \\
\hline
\end{tabular}


The preferred summary statistic is the simple average that includes Khan's Turkey (pardon the pun) and gives a PE of -1.3654 with a SE of 0.7892 .

\section{I.8 Less Developed Countries (IDC)}

Table A8 1ists the avallable estimates from Khan [1974]. The preferred summary statistic is the simple average that excludes the Ghana estimate, giving a PE of -1.4708 with a SE of 0.7176 .

\section{I.9 Summary}

Table A9 collects together the various preferred summary statistics presented above, along with the PE adopted by Whalley [1984].

\section{Import Income Elasticities}

\section{1 EEC}

Table A10 1ists the estimates from Houthakker and Magee [1969] and the import weights listed in Table A1. The preferred summary statistic is the weighted average, giving a PE of 1.8112 with a SE of 0.1992 .

\section{II.2 U.S.}

Houthakker and Magee [1969] provide a PE of 1.51 with a SE of 0.1249 . We adopt this estimate here.

\section{3 Japan}

Houthakker and Magee [1969] provide a PE of 1.23 with a SE of 0.0942. We adopt this estimate here.

\section{II.4 Canada}

Houthakker and Magee [1969] provide a PE of 1.20 with a SE of 0.0736 . We adopt this estimate here. 
TABLE A9

Import Price Elasticities: Summary

\begin{tabular}{lllll} 
& & \multicolumn{2}{c}{ Literature } & Wha1ley \\
\cline { 3 - 4 } Weight & Region & PE & SE & PE \\
\hline 195.3 & EEC & -1.1090 & .3504 & -0.91 \\
150.8 & U.S. & -1.4132 & .3412 & -1.66 \\
71.2 & Japan & -1.0241 & .3216 & -0.78 \\
42.0 & Canada & -1.1943 & .3633 & -1.02 \\
154.9 & ODC (excluding Canada) & -0.9000 & .5115 & -1.02 \\
196.9 & ODC (including Canada) & -0.9624 & .4818 & -1.02 \\
83.8 & OPEC & -0.8970 & .3833 & -0.89 \\
63.1 & NIC & -1.3654 & .7892 & -1.38 \\
94.8 & LDC & -1.4708 & .7176 & -1.28 \\
\cline { 5 - 5 } & Weighted Average & -1.1601 & .4524 & -1.1303 \\
\hline
\end{tabular}

Note: Weights refer to imports in 1977, and are taken from Whalley [1984; Table 3.13] (the value for Canada is taken from the IMF Direction of Trade).

TABLE A10

Import Income Elasticities for EEC

Source: Houthakker and Magee [1969]

\begin{tabular}{rlll} 
Weight & Country & PE & SE \\
\hline 64.557 & United Kingdom & 1.66 & .1575 \\
101.419 & West Germany & 1.80 & .1043 \\
48.111 & Italy & 2.19 & .3380 \\
46.574 & Netherlands & 1.89 & .1662 \\
70.494 & France & 1.66 & .1783 \\
40.265 & Belgium-Luxembourg & 1.94 & .1481 \\
13.237 & Denmark & 1.31 & .2885 \\
\cline { 2 - 4 } & Simple Average & 1.7786 & .1973 \\
& Weighted Average & 1.8112 & .1992 \\
\hline
\end{tabular}

Note: Weights as in Table A1. 
II.5 ODC

Table A11 1ists several estimates from Houthakker and Magee [1969]. The estimates for the various Developed Countries (DC) are also listed for completeness, given that whalley [1984] uses averages of DC estimates for ODC. The preferred summary statistic is the weighted average over ODC, giving a PE of 1.4125 with a SE of 0.2240 . The weighted average over DC is not dramatically different.

\section{II.6 OPEC}

Houthakker and Magee [1969] report estimates for Mexico ( $P E=0.52$, $\mathrm{SE}=0.0947)$ and Khan [1975] reports estimates for Venezuela (PE $=0.239$, $S E=0.2234$ ). Simple averages of these two provide a PE of 0.3795 with a SE of 0.15905 .

\section{II.7 NIC}

- Table A12 lists estimates from Khan [1974], excluding a negative estimate for Uruguay. The preferred summary statistic is the weighted average excluding Chile, giving a PE of 0.3047 with a SE of 0.2396 .

\section{II.8 IDC}

Table A13 lists estimates mainly from Khan [1974] (the estimate for India is from Houthakker and Magee [1969]). The preferred summary statistic is the weighted average excluding Ghana, giving a PE of 0.8991 with a SE of 0.2442 .

\section{II.9 Summary}

Table A14 collects together the various preferred summary statistics presented above, along with the PE adopted by Whalley [1984]. Several points to note about the Whalley estimates: (i) his estimate for ODC is incorrectly taken from the Portugal export estimate of Houthakker and Magee 
A12

TABLE A11

Import Income Elasticities for ODC

Source: Houthakker and Magee [1969]

\begin{tabular}{rrlrl} 
Weight & DC or ODC & Country & PE & SE \\
\hline 20.114 & ODC & Sweden & 1.42 & .3447 \\
13.667 & ODC & Australia & .90 & .1779 \\
17.929 & ODC & Switzerland & 1.81 & .2315 \\
12.873 & ODC & Norway & 1.40 & .1304 \\
4.981 & ODC & Portugal & 1.39 & .0777 \\
370.886 & DC & EEC & 1.779 & .1973 \\
157.546 & DC & U.S. & 1.51 & .1249 \\
71.325 & DC & Japan & 1.23 & .0942 \\
42.052 & "DC" & Canada & 1.20 & .0736 \\
& & Simple Average (ODC) & 1.3840 & .1924 \\
& & Weighted Average (ODC) & 1.4125 & .2240 \\
& & Simple Average (DC) & 1.4061 & .1718 \\
& & Weighted Average (DC) & 1.5958 & .1668 \\
\hline
\end{tabular}

Note: Weights as in Table A1.

TABLE A12

Import Income Elasticities for NIC

Source: Houthakker and Magee [1969]

\begin{tabular}{clcc} 
Weight & Country & PE & SE \\
\hline 4.163 & Argentina & .143 & .5107 \\
13.254 & Brazil & .107 & .0385 \\
2.26 & Chile & .004 & .0571 \\
2.448 & Colombia & .210 & .0492 \\
.978 & Costa Rica & 2.046 & 1.1 \\
1.508 & Ecuador & .555 & .0793 \\
5.796 & Turkey & .554 & .4817 \\
& Simple Average & .5170 & .3309 \\
& Simple Average (excluding Chile) & .6025 & .3766 \\
& Weighted Average & .2824 & .2260 \\
& Weighted Average (excluding Chile) & .3047 & .2396 \\
\hline
\end{tabular}

Note: Weights as in Table Al. 
TABLE $A 13$

Import Income Elasticities for LDC

Source: Khan [1974], except India (due to Houthakker and Magee [1969]).

\begin{tabular}{llcc} 
Weight & Country & PE & SE \\
\hline 1.304 & Ghana & 0.238 & 7.9333 \\
6.454 & India & 1.430 & .2144 \\
3.359 & Morocco & 0.213 & .1885 \\
2.555 & Pakistan & 1.021 & .2774 \\
4.27 & Philippines & 0.668 & .3340 \\
0.656 & Sri Lanka & 0.218 & .1079 \\
\cline { 2 - 4 } & Simple Average (excluding India) & 0.6313 & 1.5092 \\
& Simple Average (excluding Ghana) & 0.4716 & 1.7682 \\
& Simple Average (excluding India and & 0.5300 & 0.2244 \\
& Simple Average (Ghana) & & 0.2269 \\
& & 0.8991 & .2442 \\
& Weighted Average (excluding Ghana) & 0.700 &
\end{tabular}

Note: Weights as in Table A1.

TABLE A 14

Import Income Elasticities: Summary

\begin{tabular}{rllll} 
& & \multicolumn{2}{c}{ Literature } & Whalley \\
\cline { 3 - 4 } Weight & Region & PE & SE & PE \\
\hline 195.3 & EEC & 1.8112 & .1992 & 1.77 \\
150.8 & U.S. & 1.51 & .1249 & 1.51 \\
71.2 & Japan & 1.23 & .0942 & 1.23 \\
42.0 & Canada & 1.20 & .0736 & 1.41 \\
154.9 & ODC (excluding Canada) & 1.4125 & .2240 & 1.41 \\
196.9 & ODC (including Canada) & 1.3672 & .1919 & 1.41 \\
83.8 & OPEC & 0.3795 & .1591 & 0.24 \\
63.1 & NIC & 0.3047 & .2396 & 1.29 \\
94.8 & LDC & 0.8991 & .2442 & 1.43 \\
& & 1.2554 & .1797 & 1.3736 \\
\hline
\end{tabular}

Note: Weights as in Table A9. 
[1969], where the correct import estimate is 1.39 (thus there is no significant error involved); (ii) his estimate for OPEC is taken from Khan [1975] and not Khan [1974] as reported; and (iii) his NIC estimate of 1.29 is taken from the Turkey estimate of Taplin [1973], which employs an unusually goofy explanatory variable to proxy "income" (viz., "last period's exports"!).

\section{Export Price Elasticities}

Note that in the final application in Whalley's GE model we will only be using one elasticity for all regions and all commodities. Consequently we do not need to be as exhaustive in reviewing the Iiterature as we have been above.

\section{III.1 EEC}

Tables A15 and A16 11st available estimates for various EEC member nations. The preferred summary statistic is the weighted average shown in Table A15, giving a PE of -1.2594 with a SE of 0.3304 .

\section{III.2 U.S.}

Table A17 1ists some estimates from the literature. We adopt the simple average of these values, giving a PE of -1.2931 and a SE of 0.3580 .

\section{III.3 Japan}

Table A18 1ists some estimates from the literature. The preferred summary statistic is the simple average, giving a PE of -1.3367 and a SE of 0.4614 .

\section{III.4 Canada}

Table A19 1ists some estimates from the literature. The preferred statistic is the simple average, giving a PE of -0.9052 and a SE of 0.2473 . 
A15

TABLE A15

Export Price Elasticities for EEC

\begin{tabular}{llcc} 
Weight & Country & PE & SE \\
\hline 64.997 & France & -1.5169 & .2663 \\
118.017 & West Germany & -1.2480 & .2725 \\
45.314 & Italy & -0.9947 & .2801 \\
58.169 & United Kingdom & -0.9959 & .4330 \\
43.741 & Netherlands & -1.3398 & .4974 \\
10.064 & Denmark & -1.2722 & .3314 \\
37.511 & Belgium-Luxembourg & -1.4799 & $\mathrm{NA}$ \\
& & -1.2639 & .3468 \\
& Simple Average & -1.2594 & .3304 \\
\hline
\end{tabular}

Note: Weights are 1977 Exports in Billions of U.S. \$ from IMF, Direction of Trade. 


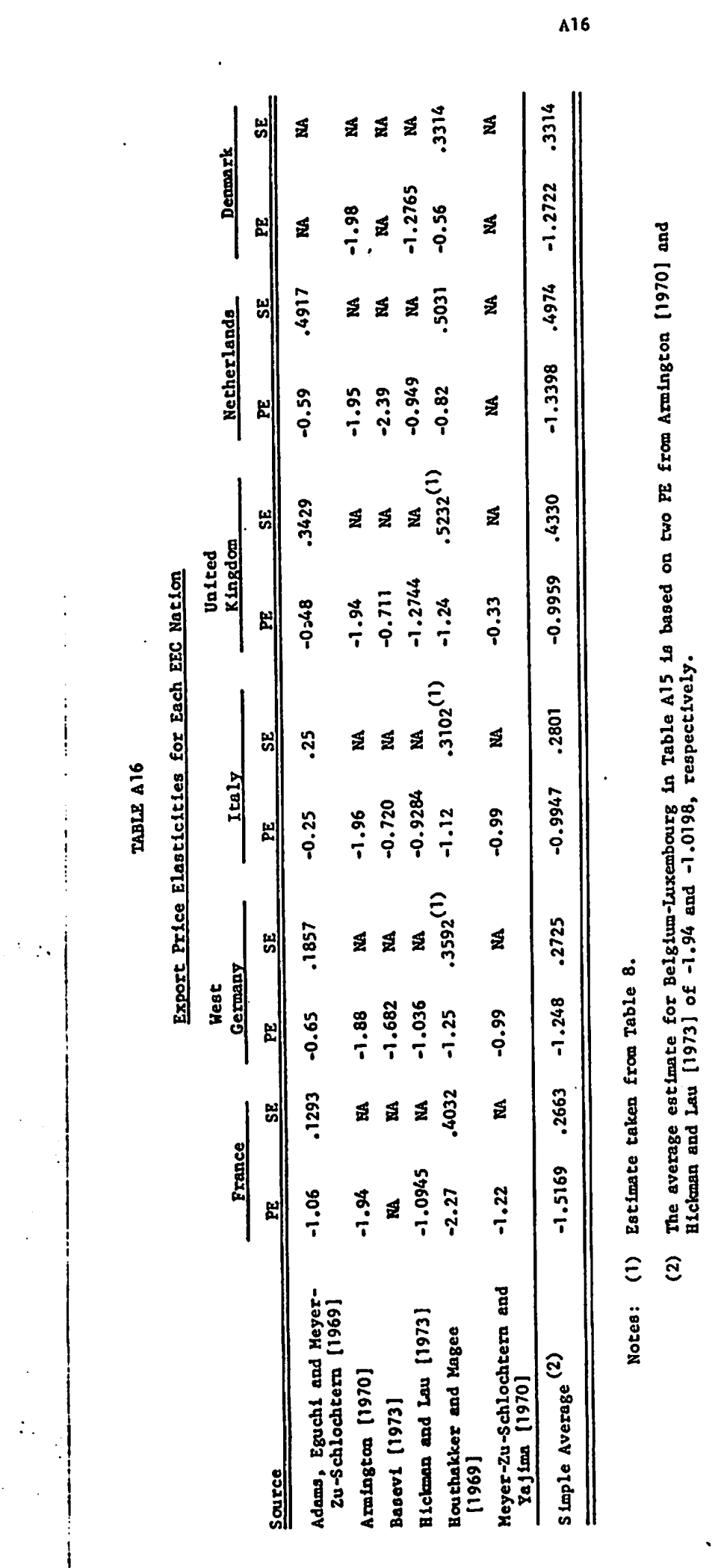


TABLE A17

Export Price Elasticities for the U.S.

\begin{tabular}{lcc} 
Source & PE & SE \\
\hline 1. Samuelson [1973; LR estimate] & -1.13 & NA \\
2. Adams, Eguchi and Meyer-Zu-Schlochtern [1969] & -0.60 & 0.25 \\
3. Stone [1979; Average I] & -1.59 & NA \\
4. Armington [1970] & -1.79 & NA \\
5. Hickman and Lau [1973; LR estimate] & -1.3781 & NA \\
6. Basevi [1973; LR estimate] & -1.047 & NA \\
7. Houthakker and Magee [1969] & -1.51 & .46605 \\
8. Junz and Rhomberg [1965] & -1.30 & NA \\
\hline Simple Average & -1.2931 & .3580 \\
\hline
\end{tabular}

TABLE A 18

Export Price Elasticities for Japan

\begin{tabular}{lll} 
Source & PE & SE \\
\hline 1. Samuelson [1973; LR estimate] & -1.04 & NA \\
2. Adams, Eguchi and Meyer-Zu-Schlochtern [1969] & -0.71 & .4733 \\
3. Stone [1979; Average I] & -2.08 & NA \\
4. Basevi [1973] & -2.378 & NA \\
5. Hickman and Lau [1973] & -0.436 & NA \\
6. Meyer-Zu-Schlochtern and Yajima [1970] & -1.25 & NA \\
7. Houthakker and Magee [1969] & -0.80 & .4494 \\
8. Junz and Rhomberg [1965] & -2.0 & NA \\
\hline Simple Average & -1.3367 & .4614 \\
\hline
\end{tabular}


TABLE A19

Export Price Elasticities for Canada

\begin{tabular}{lcc}
\multicolumn{1}{l}{ Source } & PE & SE \\
\hline 1. Samuelson [1973; LR estimate] & -1.10 & $\mathrm{NA}$ \\
2. Adams, Eguchi and Meyer-Zu-Schlochtern [1969] & -0.23 & .2875 \\
3. Hickman and Lau [1973; LR estimate] & -0.8447 & $\mathrm{NA}$ \\
4. Armington [1970] & -1.95 & $\mathrm{NA}$ \\
5. Houthakker and Magee [1969; Table 1] & -0.59 & .2070 \\
6. Basevi [1973] & -0.587 & $\mathrm{NA}$ \\
7. Junz and Rhomberg [1965] & -1.0 & $\mathrm{NA}$ \\
8. Meyer-Zu-Schlochtern and Yajima [1970] & -0.94 & $\mathrm{NA}$ \\
\hline Simple Average & -0.9052 & .2473 \\
\hline
\end{tabular}




\section{III.5. Other Developed Countries}

Table A20 1ists readily available estimates, giving a simple average with a PE of -0.8798 and a SE of 0.3588 . Note that this excludes Canada.

\section{6 OPEC}

Whalley [1984] reports and uses a PE of -0.84 for Venezuela from Khan [1975], but we are unable to locate this estimate in that reference. Houthakker and Magee [1969] do report an estimate of plus 0.84 for Venezuela, and this is presumably the source of Whalley's estimate. Our preferred estimate is taken from the Canadian export price elasticity for Crude Petroleum and Natural Gas reported in Officer and Hurtibase [1969]; thus we assume a PE of -1.17 with no available SE.

\section{III.7 Newly Industrialized Countries}

Table A21 lists available estimates, giving a simple average with a $\mathrm{PE}$ of -0.5272 and $a \mathrm{SE}$ of 0.2172 .

\section{III.8 Less Developed Countries}

Table A22 lists available estimates, giving a simple average (excluding Khan's Colombia estimate) with a PE of -0.6620 and a SE of 0.1964 .

\section{III.9 Summary}

Table A23 collects the preferred summary statistics noted above and the estimates used by Whalley [1984]. A weighted average is computed using 1977 exports as 1isted in Whalley [1984; Table 3.13]. 
TABLE A20

Export Price Elasticities for ODC

\begin{tabular}{|c|c|c|c|}
\hline Source & Country & $\mathrm{PE}$ & SE \\
\hline Houthakker and Magee [1969] & $\begin{array}{l}\text { Australia } \\
\text { Austria } \\
\text { Spain } \\
\text { Switzerland }\end{array}$ & $\begin{array}{l}-0.17 \\
-1.30 \\
-0.65 \\
-0.58\end{array}$ & $\begin{array}{l}.1241 \\
.4319 \\
.7065 \\
.1726\end{array}$ \\
\hline Junz and Rhomberg [1965] & Austria & -1.2 & $\mathrm{NA}$ \\
\hline \multirow[t]{2}{*}{ Hickman and Lau [1973] } & $\begin{array}{l}\text { Australla } \\
\text { Austria } \\
\text { Norway } \\
\text { Sweden } \\
\text { Switzerland } \\
\text { Finland } \\
\text { Greece } \\
\text { Portugal } \\
\text { Spain } \\
\text { New Zealand }\end{array}$ & $\begin{array}{l}-0.7411 \\
-0.9315 \\
-0.8081 \\
-1.9887 \\
-1.0110 \\
-0.8136 \\
-0.6198 \\
-1.0253 \\
-0.6107 \\
-0.7466\end{array}$ & $\begin{array}{l}\text { NA } \\
\text { NA } \\
\text { NA } \\
\text { NA } \\
\text { NA } \\
\text { NA } \\
\text { NA } \\
\text { NA } \\
\text { NA } \\
\text { NA }\end{array}$ \\
\hline & mple Average & -0.8798 & 0.3588 \\
\hline
\end{tabular}

TABLE A21

Export Price Elasticities for NIC

\begin{tabular}{llll} 
Source & Country & PE & \multicolumn{1}{c}{ SE } \\
\hline Houthakker and Magee [1969] & $\begin{array}{l}\text { Argentina } \\
\text { Brazil }\end{array}$ & -0.55 & .2644 \\
& Chile & -0.39 & .1653 \\
& & -0.09 & .1915 \\
Khan [1974] & Argentina & -0.242 & .2396 \\
& Brazil & -0.083 & .1596 \\
Chile & -0.109 & .0381 \\
& Costa Rica & -1.248 & .6271 \\
& Ecuador & -0.623 & .1143 \\
& Turkey & -1.410 & .1551 \\
& & & .2172 \\
& & &
\end{tabular}


A21

TABLE A22

Export Price Elasticities for LDC

\begin{tabular}{llcc} 
Source & Country & PE & SE \\
\hline Houthakker and Magee [1969] & India & -0.23 & .2233 \\
& Colombia & -0.18 & .1343 \\
& Peru & -0.70 & .2349 \\
Khan [1974] & Colombia & -0.258 & 2.15 \\
& Ghana & -0.438 & .2212 \\
& India & -0.544 & 1.2651 \\
& Morocco & -0.705 & .3490 \\
& Pakistan & -1.824 & .6633 \\
& Pern & -1.245 & .3259 \\
& Sri Lanka & -0.100 & .5 \\
& & -0.6216 & .3917 \\
& Simple Average & -0.6620 & .1964 \\
& Simple Average & -0.56 & \\
& (excluding Khan's & & \\
& Colombia) & &
\end{tabular}

TABLE A23

Export Price Elasticities: Summary

\begin{tabular}{|c|c|c|c|c|}
\hline \multirow[b]{2}{*}{ Weight } & \multirow[b]{2}{*}{ Region } & \multicolumn{2}{|c|}{ Literature } & \multirow{2}{*}{$\frac{\text { Whalley }}{P E}$} \\
\hline & & $\mathrm{PE}$ & $S E$ & \\
\hline \multirow[t]{3}{*}{$\begin{array}{c}212.4 \\
117.9 \\
80.5 \\
43.373 \\
120.5 \\
145.6 \\
53.7 \\
81.9\end{array}$} & $\begin{array}{l}\text { EEC } \\
\text { U.S. } \\
\text { Japan } \\
\text { Canada } \\
\text { ODC } \\
\text { OPEC } \\
\text { NIC } \\
\text { LDC }\end{array}$ & $\begin{array}{l}-1.2594 \\
-1.2931 \\
-1.3367 \\
-0.9052 \\
-0.8798 \\
-1.17 \\
-0.5272 \\
-0.6620\end{array}$ & $\begin{array}{c}.3304 \\
.3580 \\
.4614 \\
.2473 \\
.3588 \\
\text { NA } \\
.2172 \\
.1964\end{array}$ & $\begin{array}{l}-1.14 \\
-1.41 \\
-1.25 \\
-1.26 \\
-1.26 \\
-0.83 \\
-1.41 \\
-1.82\end{array}$ \\
\hline & Simple Average & -1.0042 & .3099 & -1.2975 \\
\hline & Weighted Average & -1.0816 & .3256 & -1.2398 \\
\hline
\end{tabular}




\section{References to Appendix A}

Adams, F. G., Eguchi, H., and Meyer-Zu-Schlochtern, F., An Econometric

Analysis of International Trade (Paris: OECD, 1969).

Armington, P. S., "Adjustment of Trade Balances: Some Experiments with a

Model of Trade Among Many Countries," IMF Staff Papers, V. XVII, 1970,

Pp. 488-517.

Barber, T. S., "Aggregation. Error and Estimates of the U.K. Import Demand Function," in K. Hilton and D. E. Heathfield (eds.), The Econometric Study of the United Kingdom (London: Macmillan, 1970a, pp. 115-45). - The Determinants of Britain's Visible Imports, 1949-1966 (London:

Chapman and Hall for the Department of Applied Economics, University of Cambridge, December 1970b).

Basevi, G., "Commodity Trade Equations in Project LINK," In R. J. Ball (ed.), The International Linkage of National Economic Models (Amsterdam: North-Holland, 1973).

Branson, W. H., "The Trade Effects of the 1971 Currency Realignments," Brookings Papers on Economic Activity, 1972:1, pp. 15-69.

Burgess, D. F., "Production Theory and the Derived Demand for Imports," Journal of International Economics, V. 4, May 1974, pp. 103-118. , "Duality Theory and Pitfalls in the Specification of Technologies," Joumal of Econometrics, V. 3, 1975, pp. 105-121.

Goldstein, M. and Khan, M. S., "Large Versus Small Price Changes and the Demand for Imports," IMF staff Papers, V. XXIII, March 1976, PP. 200-225. , "Income and Price Effects in Foreign Trade," in P. B. Kenan and

R. W. Jones (eds.), Handbook of International Economics (Amsterdam: North-Holland, 1983).

Heien, D. M., "Structural Stability and the Estimation of International Import Price Elasticities," Kyklos, V. 21, 1968, pp. 695-711. 
Hickman, B. G. and Lau, L. J., "Elasticities of Substitution and Export Demands in a World Trade Model," European Economic Review, V. 4, 1973, Pp. 347-380.

Houthakker, H. S., and Magee, S. P., "Income and Price Elasticities in World Trade," Review of Economics and Statistics, V. 51, May 1969, pp. 111-125.

Joy, J. and Stolen, J. D., "The Change in the U.S. Import Demand Function from the 1950's to the 1960's," Review of Economics and Statistics, V. IVII, February 1975, pp. 109-111.

Junz, H. B., and Rhomberg, R. R., "Prices and Export Performance of Industrial Countries, 1953-63," IMF Staff Papers, V. XII, July 1965, pp. 224-271.

Khan, M. S., "Import and Export Demand in Developing Countries," IMF Staff Papers, V. XXI, November 1974, Pp. 678-693. , "The Structure and Behaviour of Imports of Venezuela," IMF Staff Papers, V. LVII, May 1975, pp. 221-224.

Kohli, U. R., "Relative Price Effects and the Demand for Imports," Canadian Journal of Economics, V. 15, 1982, pp. 205-219. , "The Le Châtelier Principle and the Demand for Imports in the Short Run and the Medium Run: Australia, 1959-60/1978-79," Economic Record, V. 59, 1983, pp. 149-165.

Kreinin, M., "Price Elasticities in International Trade," Review of Economics and Statistics, V. XIIX, November 1967, Pp. 510-516.

Leamer, E. E., "Empirically Weighted Indexes for Import Demand Functions," Review of Economics and Statistics, V. LV, November 1973, Pp. $441-449$. Meyer-Zu-Schlochtern, F. and Yajima, A., "OECD Trade Model: 1970 Version," OECD Economic Outlook (Paris: OECD, 1970) .

Miller, J. C., and Fratianni, M., "The Lagged Adjustment of U.S. Trade to Prices and Income," Journal of Economics and Business, V. 26, Spring 1974, pp. 191-198. 
Officer, L. H., and Hurtubise, J. R., "Price Effects of the Kennedy Round on Canadian Trade," Review of Economics and Statistics, V. LI, August 1969, PP. 320-333.

Samuelson, L., "A New Model of World Trade," OECD Economic Outlook (Paris: OECD, 1973)

Sarantides, S. A., "Import Demand Functions for Greece, 1953-64," Economia Internazionale, V. XXV, February 1972, PP. 107-114.

Stern, R. M., Baum, C. F., and Greene, M. N., "Evidence on Structural Change in the Demand for Aggregate U.S. Imports and Exports," Journal of Political Economy, V. LXXXVII, 1979, Pp. 179-192.

Stern, R. M., Francis, J., and Schumacher, B., Price Elasticities in International Trade: An Annotated Bibliography (London: Macmillan for the Trade Policy Research Centre, 1976).

Stone, J. A., "Price Elasticities of Demand for Imports and Exports: Industry Estimates for the U.S., the E.E.C. and Japan," Review of Economics and Statistics, V. LXI, 1979, Pp. 117-123.

Taplin, G. R., "A Model of World Trade," in R. J. Ball (ed.), The International Linkage of National Economic Models (Amsterdam: North-Holland, 1973). Whalley, J., Trade Liberalization Among Major World Trading Areas: A General Equilibrium Approach (Boston: MIT Press, 1984). 


\section{APPENDIX B}

\section{Elasticities of Substitution between Capital and Labour}

This appendix details the estimation procedure used for the revised estimates of the factor substitution elasticities for the Whalley model. These values were reported in the text and used in the simulations of that model. Annual data for twenty-two two-digit industries corresponding to Manufacturing industries, the Mining industry and the Energy industry were available for the U.S. for the years 1947 to 1982. Comparable data for seven other industries corresponding to the Non-Traded and Agriculture Food industries were available for the years 1958 to 1976 from the National Income and Product Accounts of the United States (the 1929-1976 Statistical Tables). These industries are assigned the letters in Table B1.

Estimates of the elasticity of substitution for each industry were computed and then estimates for the aggregated industries were calculated as weighted averages of the component industry point estimates and standard errors.

OLS estimates of the elasticity of capital-labour substitution for the CES production form were estimated using the relation

$$
\ln \frac{y}{\ell}=\alpha+\beta \ln (\underset{p}{(-)},
$$

where $\hat{\beta}$ will be an estimate of the elasticity of substitution. The oLs estimates were all rejected at standard confidence levels since the Durbin-Watson statistics were all below the lower limit value (indicating the presence of positive first-order autocorrelation). Maximum likelihood estimates were computed on the assumption of an AR (1) error structure and 
these results appear in Table $\mathrm{B} 2$.

Estimates for the aggregated industries were computed by weighting the component industry estimates by that industry's share of aggregate 1977 industry output. In some component industries, the estimates were negative and thus inconsistent with the maximization model used to estimate the elasticities. In these cases negative estimates were excluded to arrive at the two estimates for the Agriculture and Food; Mining, and Non-Traded Industries (if we alternatively set these "a priori" unacceptable estimates to zero, and weight that zero estimate positively, we obtain pooled point estimates of $0.5895,0.2900$ and 1.5923 , with pooled standard errors 0.0699 , 0.0715 and 0.8070 , respectively, for each of these three aggregated sectors). The resulting estimates appear in Table $\mathrm{B} 3$.

We appreciate that there are many corrections to the available data that might be made, alternative (albeit less readily accessible) data that might have been employed, and alternative estimation procedures that could have been used. Our objective is not to provide definitive values for these factor substitution elasticities, but simply to develop estimates that are data-based and that provide us with a well-defined probability distribution. In any event, the elasticities in question here turn out not to be as important for the trade policy) simulations of the whalley model considered in the text as the trade elasticities considered in Appendix A. 
TABLE B1

Aggregation Used For Whalley Model From Data Available AGGREGATE INDUSTRY

COMPONENT INDUSTRIE'S

\begin{tabular}{|c|c|c|}
\hline $\begin{array}{l}\text { AGRICULTURE } \\
\text { and } \\
\text { FOOD }\end{array}$ & A & $\begin{array}{l}\text { Agriculture Forestry and } \\
\text { Fisheries } \\
\text { Food and Product }\end{array}$ \\
\hline MINING & $\begin{array}{l}10 \\
14\end{array}$ & $\begin{array}{l}\text { Metal Mining } \\
\text { NonMetallic Minerals Except } \\
\text { Fuels }\end{array}$ \\
\hline ENERGY & $\begin{array}{r}* 12 \\
13 \\
29\end{array}$ & $\begin{array}{l}\text { Coal, Lignite Mining } \\
\text { oil and Gas Extraction } \\
\text { Petroleum and Product }\end{array}$ \\
\hline NON MECHANICAL MANUFACTURING & $\begin{array}{l}21 \\
22 \\
23 \\
24 \\
25 \\
26 \\
27 \\
28 \\
30 \\
31 \\
32 \\
33 \\
34 \\
39\end{array}$ & $\begin{array}{l}\text { Tobacco Manufactors } \\
\text { Textile Mill Products } \\
\text { Apparel and Product } \\
\text { Lumber and Product } \\
\text { Furniture and Fixtures } \\
\text { Paper and Product } \\
\text { Print and Publishing } \\
\text { Chemical and Product } \\
\text { Rubber and Plastics } \\
\text { Leather and Product } \\
\text { Stone Clay and Glass } \\
\text { Primary Metals } \\
\text { Fabricated Metal Product } \\
\text { Miscellaneous Manufactures }\end{array}$ \\
\hline $\begin{array}{l}\text { MACHINERY AND TRANSPORT } \\
\text { EQUIPMENT }\end{array}$ & $\begin{array}{l}35 \\
36 \\
38\end{array}$ & $\begin{array}{l}\text { Machinery } \\
\text { Electrical Machines } \\
\text { Instruments }\end{array}$ \\
\hline NON TRADED & $\begin{array}{r}* 15 \\
* 16 \\
* 17 \\
\text { B } \\
\text { C } \\
\text { D } \\
\text { E } \\
\text { F } \\
\text { G }\end{array}$ & $\begin{array}{l}\text { General Building Contracts } \\
\text { Heavy Building Contracts } \\
\text { Special Trade Contracts } \\
\text { Transportation and Public } \\
\text { Utility } \\
\text { Wholesale } \\
\text { Retail } \\
\text { Finance } \\
\text { Government } \\
\text { Services }\end{array}$ \\
\hline
\end{tabular}

Notes: Data for component industries A through $G$ available for 1958-1976; all other series available 1947-1982, except for some minor instances of incomplete series indicated by an asterisk (in these cases the time series is truncated slightly due to the use of new statistical procedures). 
TABLB B2

Detailed Elasticity of Substitution Estimates

Sectors Share (weight) Point Estimate standard Error

AGRICULTURE AND FOOD

A

20

MINING

10

14

ENERGY

13

29
.3762

.6238

.3186

.6814

.5962

.4038
$-.1617$

.945

.11854

.0407

NON-MECHANICAL MANUFACTURING

$\begin{array}{lccc}21 & .0257 & .8386 & .0893 \\ 22 & .0635 & .9266 & .0766 \\ 23 & .0671 & 1.193 & .0304 \\ 24 & .0630 & .7449 & .1136 \\ 25 & .0293 & 1.119 & .0891 \\ 26 & .0754 & 1.089 & .1078 \\ 27 & .0918 & .9067 & .1474 \\ 28 & .1598 & 1.009 & .0268 \\ 30 & .0652 & .9717 & .0820 \\ 31 & .0132 & .7473 & .1647 \\ 32 & .0589 & .9582 & .1317 \\ 33 & .1169 & .9110 & .2411 \\ 34 & .1360 & .7021 & .1334 \\ 39 & .0339 & 1.189 & .0545\end{array}$

\section{HEAVY MANUFACTURING}

35

36

38

NON TRADED
.4772

.3913

.1326
.4337

.0853
.0767

.1050

.0886

.1209

$\begin{array}{ll}\text { B } & .137 \\ \text { C } & .113 \\ \text { D } & .149 \\ \text { E } & .215 \\ \text { F } & .198 \\ \text { G } & .187\end{array}$

$$
\begin{gathered}
1.884 \\
2.062 \\
.5031 \\
2.055 \\
-1.18 \\
3.125
\end{gathered}
$$

.0897 .0267 .1651 
TABLE B3

Final Elasticity of Substitution Estimates

Sector

Point Estimate

Standard Error

1. Agriculture and Food

0.9450

0.0407

2. Mining

0.4256

0.1050

3. Energy

0.2930

0.1016

4. Non-Mechanical Manufacturing

0.9387

0.1084

5. Heavy Manufacturing

1.1182

0.0751

6. Non-Traded

1.9885

0.4769 


\section{APPENDIX C}

\section{A Complete Unconditional Sensitivity Analysis}

In this Appendix we pursue the question of the adequacy of a CSSA by imposing extreme restrictions on a (hypothetical) GE model. We then undertake a complete and exhaustive USSA. The purpose of this exercise is to illustrate how "fragile" simple GE models can be, and to demonstrate why an USSA may be warranted.

The model obviously had to be a minimal specification to make the presentation of complete unconditional sensitivity analysis manageable. The model was therefore designed to have as few parameters and exogenous variables as possible. The resulting model features include: (i) Two factors are used to produce two goods. There is only one consumer; (ii) There is no government so there are no taxes; (iii) The tastes of the sole consumer are specified by a two-good CES utility function indexed by only one parameter $\beta$, the distribution parameter (or "weight") on good 1. The weight on good 2 is therefore (1- $\beta$ ); (iv) Technologies for producing the two goods with two factors are specified with CES production functions, each assumed to have constant returns to scale with efficiency parameters equal to one; $(v)$ The distribution parameters in the production functions are indexed by only one parameter $\delta$, the weight on factor 1 in producing good 1 , and the (same) weight on factor 2 in producing good 2; (vi) If $\delta=0.5$ then $1-\delta=0.5$, the production possibility frontier is linear and tases become irrelevant to prices, since technology alone determines the tradeoffs; (vii) The elasticity of substitution $\sigma$ is the same for both production functions and for the single utility function; (viii) The endowment of factor 1 is unity, so the ratio of the endowment of factor 2 to factor $1, x$, a scalar, suffices to specify 
emdowments; and (ix) The price of factor $1\left(p_{1}\right)$ is the numeraire, so there is only one unknown relative factor price, $p=\left(p_{2} / p_{1}\right)$. The entire GE model can therefore be solved as one rolalive factor price as a (closed form, exacl, global) function of three parameters and one exogenous variable: $p=$ $f(\sigma, \beta, \delta, x)$.

The exhaustive nature of our experimental design requires that we explore all combinations of settings of the four determinants. The endowment of factor 1 relative to factor 2 is symmetric, so only one direction needs to be explored. We therefore limit the exploration of endowment effects to two settings: 1.0 and 2.0 . Similar symmetry arguments permit $\delta$ to range from 0.5 to 0.9 with incremlents of 0.2 . The single parameter $\beta$ indexing tastes is set to three values: $01,0.5$ and 0.9 . Finally, the span of the elasticity of substitution is made log-linear, ranging from 0.2 to 5 as shown in the row headings of Table $\mathrm{Cl}$. This experimental design means that the model is solved for the relative factor price for all possible combinations of settings of the four parameters, as shown in Table $\mathrm{cl}$.

The central question is whether the results of a given setting for two of the parameters heavily influences the interpretation of varying the other two parameters. Specifically, is the role of the elasticity of substitution and the technological distribution parameter on the relative factor price robustly identified regardless of the setting of the endowment and the tastes distribution parameter? That is, if one had only studied a given block in Table C1, would the conclusions be the same regardless of which block of the Table one chooses? The answer is clear and rather pessimistic: the analysis varies radically across the blocks of Table $\mathrm{Cl}$. The analysis of the role of (s and $\delta$ is extreacely serssitive tor the conditional values of $\beta$ and $x$. 
Factor Price Solutions for Hypothetical Hodel

(a) Endowment $X=1, B=0.1$

$\delta$

\begin{tabular}{llll} 
& & & \\
& 0.50 & 0.70 & 0.90 \\
\hline 0.20 & 1.0 & 1.2 & 1.6 \\
0.44 & 1.0 & 1.5 & 2.6 \\
0.99 & 1.0 & 1.9 & 4.5 \\
4.90 & 1.0 & 2.3 & 7.8 \\
\hline
\end{tabular}

(c) Endowment $x=1, B=0.5$

\begin{tabular}{llll} 
& \multicolumn{3}{c}{$\delta$} \\
\hline & 0.50 & 0.70 & 0.90 \\
\hline 0.20 & 1.0 & 1.0 & 1.0 \\
0.44 & 1.0 & 1.0 & 1.0 \\
0.99 & 1.0 & 1.0 & 1.0 \\
2.20 & 1.0 & 1.0 & 1.0 \\
4.90 & 1.0 & 1.0 & 1.0 \\
\hline
\end{tabular}

(e) Endowment $X=1, B=0.9$

\begin{tabular}{llll} 
& \multicolumn{3}{c}{$\delta$} \\
\hline & 0.50 & 0.70 & 0.90 \\
\hline 0.20 & 1.0 & 0.83 & 0.63 \\
0.04 & 1.0 & 0.68 & 0.39 \\
0.99 & 1.0 & 0.52 & 0.22 \\
2.20 & 1.0 & 0.44 & 0.15 \\
4.90 & 1.0 & 0.43 & 0.13 \\
\hline
\end{tabular}

(b) Endowment $X=2, B=0.1$

\section{$\delta$}

\begin{tabular}{llll}
0 & 0.50 & 0.70 & 0.90 \\
\hline 0.20 & 0.03 & 0.31 & 0.54 \\
0.44 & 0.21 & 0.31 & 0.54 \\
0.99 & 0.50 & 0.96 & 2.2 \\
4.90 & 0.87 & 2.0 & 6.8
\end{tabular}

(d) Endowment $x=2, B=0.5$

\begin{tabular}{llll} 
& \multicolumn{3}{c}{$\delta$} \\
\hline & 0.50 & 0.70 & 0.90 \\
\hline & & & \\
\hline 0.20 & 0.03 & 0.03 & 0.03 \\
0.44 & 0.21 & 0.21 & 0.21 \\
0.99 & 0.50 & 0.50 & 0.50 \\
2.20 & 0.73 & 0.73 & 0.73 \\
4.90 & 0.87 & 0.87 & 0.87 \\
\hline
\end{tabular}

(f) Endowment $X=2, B=0.9$

\begin{tabular}{llll} 
& \multicolumn{3}{c}{$\delta$} \\
\hline & 0.50 & 0.70 & 0.90 \\
& & & \\
\hline 0.20 & 0.03 & 0.03 & 0.02 \\
0.44 & 0.21 & 0.14 & 0.08 \\
0.99 & 0.50 & 0.26 & 0.11 \\
2.20 & 0.73 & 0.32 & 0.11 \\
4.90 & 0.87 & 0.37 & 0.11 \\
\hline
\end{tabular}




\section{Plots of Relative Factor Prices}

Fig. 1 Plot of Relative Factor Price

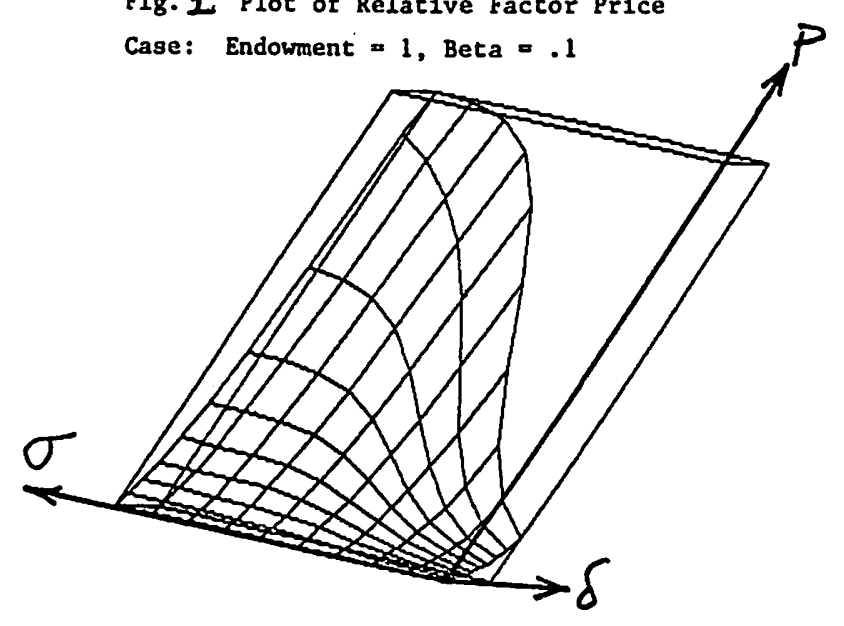

Fig. 2 Plot of Relative Factor Price

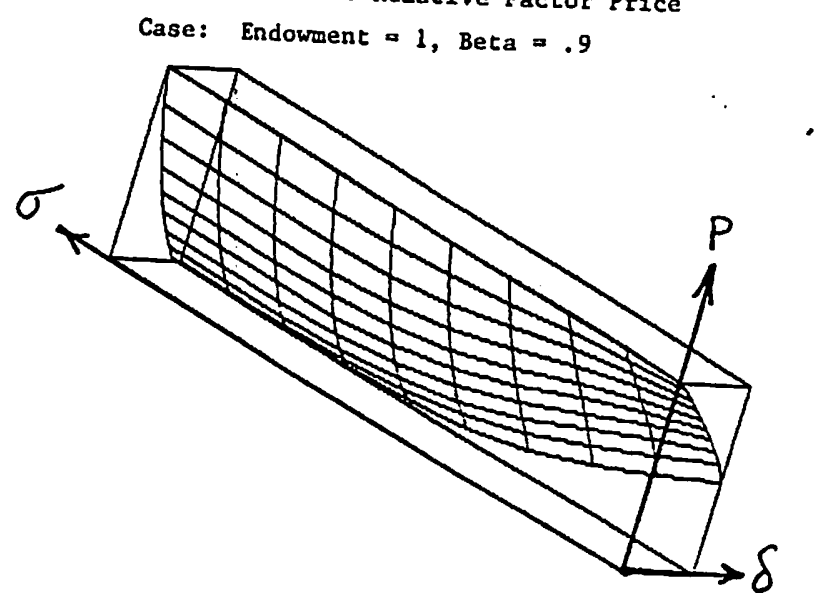

Fig. 3 Plot of Relative Factor Price

Case: Endowment $=2$, Beta $=.5$

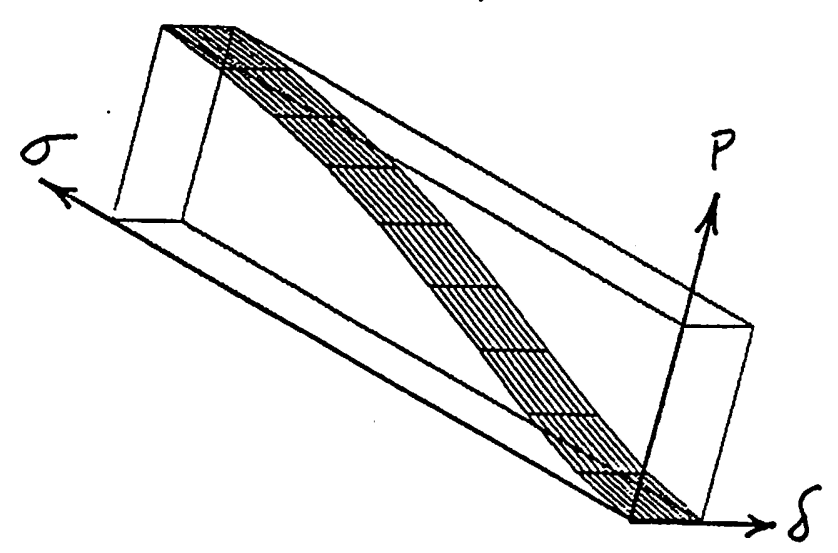

,

Fig. 4 Plot of Relative Factor Price

Case: Endowment $=2$, Beta $=.9$

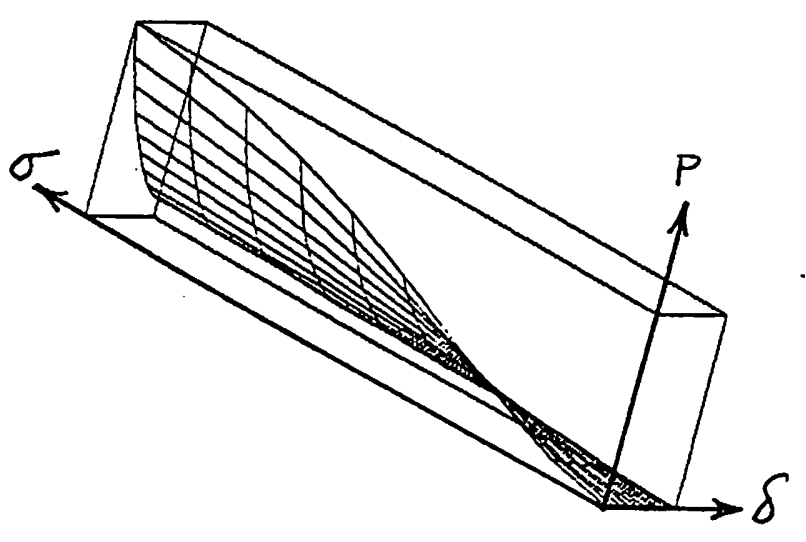


Consider Table $C 1(c)$. It shows that when $X=1$ and $\beta=0.5$, then relative factor prices are completely invariant to changes in $\delta$ and $\sigma$ (no three-dimensional figure is drawn since the factor price results would be a perfectly flat "horizontal" plane). But compare this simple pattern with that of the case where $x=2, \beta=0.9$ and $\delta=0.9$, and the pattern shown in Table C1 (f) and Figure 4. Here higher values of $\delta$ lower factor prices. When the endowment $x$ is unity and $\beta=0.9$, however, higher values of $\sigma$ lower factor prices at $\delta$ values of 0.7 or 0.9 but have no effects when $\delta=$ 0.5 .

The contrasts are perhaps most obvious in the various Figures. Clearly the relationship of $\sigma$ and $\delta$ on relative factor prices depends acutely on joint interactions with the endowment $x$ and $\beta$. The Figures show hardly any resemblance to one another.

If further analysis with more realistic models confirms these pessimistic results, then some form of USSA may be required for robust policy conclusions, regardless of the higher cost and greater complexity of presentation implied. We know of no convincing "a priori" case for arguing that the greater complexity of more realistic models somehow renders them less fragile to parameter uncertainty. 
8501C Greenwood, Jeremy and Kent P. Kimbrough. FOREIGN EXCHANGE CONTROLS IN A BLACK MARKET ECONOMY.

8502C Horstmann, Ignatius and James R. Markusen. UP YOUR AVERAGE COST CURVE: INEFFICIENT ENTRY AND THE NEN PROTECTIONISM.

8503C Gregory, Allan $W$. TESTING INTEREST RATE PARITY AND RATIONAL EXPECTATIONS FOR CANADA AND THE UNITED STATES.

8504C Kuhn, Peter and Ian Wooton. INTERNATIONAL FACTOR MOVEMENTS IN THE PRESENCE OF A FIXED FACTOR.

8505C Wong, Kar-yiu. GAINS FROM GOODS TRADE AND FACTOR MOBILITY.

8506C Weller, Paul and Makoto Yano. FUTURES MARKETS, REAL INCOME, AND SPOT PRICE VARIABILITY: A GENERAL EỌUIIIBRIUM APPROACH.

8507C Diewert, H.E. THE EFFECTS OF AN INNOVATION: A TRADE THEORY APPROACH.

8508C Ethier, Wilfred J. POREIGN DIRECT INVESTMENT AND THE MULTINATIONAL FIRM.

8509C Dinopoulos, Ellas. INSIDE THE BLACK BOX: (IN) TANGIBLE ASSETS, INTRA-INDUSTRY INVESTMENT AND TRADE.

8510C Jones, Richard, John Whalley, and Randall Higle. REGIONAL IMPACTS OF TARIFFS IN CANADA: PRELIMINARY RESULTS FROM A SMALL DIMENSIONAL NUMERICAL GENERAL EOUUILIBRIUM MODEL.

8511C Whalley, John. HDDEN CHALLENGES IN RECENT APPLIED GENERAL EQUILIBRIUM EXERCISES.

9512C Smith, Bruce. SOME COLONIAL EVIDENCE ON TWO THEORIES OF MONEY: MARYLAND AND THE CAROLINAS.

9513C Grossman, S.J., A. Melino, and R.J. Sh11ler. ESTIMATING THE CONTINUOUS TIME CONSUMPTION BASED ASSET PRICING MODEL.

8514C Romer, Paul R. TAX EFFECTS AND TRANSACTION COSTS FOR SHORT TERM MARKET DISCOUNT BONDS.

'8515C McCallum, Bennett T. ON CONSEỌUENCES AND CRITJCISMS OF MONETARY TARGETING.

8516C Dinopoulos, Ellas and Ian Wooton. A NORTH-SOUTH MODEL OF INTERNATIONAL JUSTICE.

8517C Huffman, Gregory W. A DYNAMIC EQUILIBRIUM MODEL OF ASSET PRICES AND TRANSACTION VOLUME.

-8518C Huffman, Gregory W. AN ALTERNATIVE VIEW OF OPTIMAL SEIGNIORAGE.

8519C Huffman, Gregory W. ASSET PRICING WITH HETERGENEOUS ASSETS. 
8520C Hercowitz, Zv1. THE REAL INTEREST RATE AND AGGREGATE SUPPLY.

8521C Davies, James and Michael Hoy. COMPARING INCOME DISTRIBUTIONS UNDER AVERSION TO DOWNSIDE INEQUALITY.

8522C Nguyen, Trien $T$, and John Whalley. COEXISTENCE OF EQUIIIBRIA ON BLACK AND WHITE MARKETS.

8523C Clarete, Ramon and John Whalley. INTERACTIONS BETWEEN TRADE POLICIES AND DOMESTIC DISTORTIONS: THE PHILIPPINE CASE.

8524C Hamilton, Bob, Sharlf Mohammad, and John Whalley. APPLIED GENERAL EQUILIBRIUM ANALYSIS AND PERSPECTIVES ON GROWTH PERFORMANCE.

8525C Huffman, Gregory $W$. THE LAGGED EFFECTS OF POLICY ON THE PRICE LEVEL.

8526C La1dler, David. FISCAL DEFICITS AND INTERNATIONAL MONETARY INSTITUTIONS.

8527C Goodfriend, Marvin. MONETARY MYSTIQUE: SECRECY AND CENTRAL BANKING.

8528C Nguyen, Trien $T$. and. John Whalley. GENERAL EQUILIBRIUM ANALYSIS OF PRICE CONTROLS A TWO-SECTOR COMPUTATIONAL APPROACH.

8529C Heckman, James $\mathrm{J}$. and $\mathrm{V}$. Joseph Hotz. AN INVESTIGATION OF THE LABOR MARKET EARNINGS OF PANAMANIAN MALES: EVALUATING SOURCES OF INEQUALITY.

8530C Greenwood, Jeremy and Gregory W. Huffman. A DYNAMIC EQUILIBRIUM MODEL OF INFLATION AND UNEMPLOYMENT.

8531C Freeman, Scott. INSIDE MONEY, MONETARY CONTRACTIONS, AND WELFARE.

8532C Paderanga, Cayetano Jr, and Ian Wooton. A POSITIVE VIEW OF INFANT INDUSTRIES.

8533C St-H1laire, France and John Whalley. A MICROCONSISTENT DATA SET FOR CANADA FOR USE IN REGIONAL GENERAL EQUILIBRIUM POLICY ANALYSIS.

8534C Whalley, John. OPERATIONALIZING WALRAS: EXPERIENCE WITH RECENT APPLIED GENERAL EQUILIBRIUM TAX MODELS.

8535C Melvin, James R. THE GENERAL NON-EQUIVALENCE OF TARIFFS AND IMPORT QUOTAS. 
8601C Greenwood, Jeremy and R. Preston McAfee. EXTERNALITIES AND ASYMIETRIC INFORMATION.

8602C Dinopoulos, Elias and Mordecha1 E. Kreln1n. IMPORT QUUOTAS AND VERS: A COMPARATIVE ANALYSIS IN A THREE-COUNTRY FRAMEWORK.

$8603 \mathrm{C}$ Clarete, Ramon and John Whalley. COMPARING THE MARGINAL WELFARE COSTS OF COMMODITY AND TRADE TAXES.

8604C Wigle, Randy. CANADIAN TRADE LIBERALIZATION: SCALE ECONOMIES IN A GLOBAL CONTEXT.

8605C Parkın, Michael. DOMESTIC MONETARY INSTITUTIONS AND FISCAL DEFICITS.

8606C Dinopoulos, Ellas and Ian Wooton. INTERNAT IONAL TRADE AND THE ACQUISITION OF SKILLS.

8607C Kawasaki, Selichi and John McMillan. THE DESIGN OF CONTRACTS: EVIDENCE FROM JAPANESE SUBCONTRACTING.

8608C Williamson, Stephen D. LIQUIDITY, BANKING, AND BANK FAILURES.

8609C Grossman, Gene M. and Carl Shapiro. COUNTERFEIT-PRODUCT TRADE.

8610C Deardorff, Alan V. WHY DO GOVERNMENTS PREFER NONTARIFF BARRIERS?

8611C Horstmann, Ignatius and James R. Markusen. LICENSING VERSUS DIRECT INVESTMENT: A MODEL OF INTERNALIZATION BY THE MULTINATIONAL ENTERPRISE.

8612C Thursby, Jerry G. and Marie C. Thursby. BILATERAL TRADE FLOWS, THE LINDER HYPOTHESIS, AND EXCHANGE RISK.

8613C Clarete, Ramon and John Whalley. EQUIIIBRIUM IN THE PRESENCE OF FOREIGN EXCHANGE PREMIA.

8614C Wooton, Ian. TOWARDS A COMMON MARKET: FACTOR MOBILITY IN A CUSTOMS UNION.

8615C St-Hilaire, France and John Whalley. SOME ESTIMATES OF TRADE FLOWS IN BANKING SERVICES.

8616C Evenson, Robert E. and Cayetano Paderanga Jr. RURAL LABOUR MARKETS, TRANSACTION COST AND PERTIIITY.

8617C Fried, Joel and Peter Howitt. FISCAL DEFICITS, INTERNATIONAL TRADE AND WELFARE.

8618C Trela, Irene, John Whalley, and Randy Wigle. INTERNATIONAL TRADE IN AGRICULTURE: DOMESTIC POLICIES, TRADE CONFLICTS, AND NEGOTIATING OPTIONS. 
8619C Markusen, James R. and Anthony J. Venables. TRADE POLICY WITH INCREASING RETURNS AND IMPERFECT COMPETITION: CON'TRADICTORY RESULTS FROM COMPETING ASSUMPTIONS.

8620C Hunter, Linda and James R. Markusen. PER-CAPITA INCOME AS A DETERIINANT OF TRADE.

8621C Jones, Rich and John Whalley. A CANADIAN REGIONAL GENERAL EQUILIBRIUM MODEL AND SOME APPLICATIONS.

8622C Freeman, Scott, and Gregory W. Huffman. INSIDE MONEY, OUTPUT, AND CAUSALITY.

8623C Hamilton, Colleen, and John Whalley. DEALING WITH THE NORTH: DEVELOPING COUNTRIES AND GLOBAL TRADE NEGOTIATIONS.

8624C Williamson, Stephen D. LAISSEZ FAIRE BANKING AND CIRCULATING MEDIA OF EXCHANGE.

8625C Whalley, John. WHAT HAVE WE LEARNED FROM GENERAL EQUILIBRIUM TAX POLICY MODELS?

8626C Bhatia, Kul B. SHORT RUN AND LONG RUN IN THE THEORY OF TAX INCIDENCE.

8627C Jones, Rich, and John Whalley. REGIONAL EFFECTS OF TAXES IN CANADA: AN APPLIED GENERAL EQUILIBRIUM APPROACH.

8628C Nguyen, Trien T., and John Whalley. GENERAL EQUILIBRIUM WORLD TRADE UNDER BILATERAL QUOTAS.

8629C Clarete, Ramon L., and James A. Roumasset. THE RELATIVE WELFARE COST OF INDUSTRIAL AND AGRICULTURAL PROTECTION POLICIES USING PHILIPPINE DATA. 
8701C McMillan, John, John Whalley, and Zhu Li Jing. INCENTIVE EFFECTS OF PRICE RISES AND PAYMENT-SYSTEM CHANGES ON CHINESE AGRICULTURAL PRODUCTIVITY GROWTH.

8702C Wooton, Ian. CAPITAL, SKILLS, AND INTERNATIONAL TRADE.

8703C Ryan, Cillian. TRADE IN THE PRESENCE OF ENDOGENOUS INTERMEDIATION IN AN ASYMMETRIC WORLD.

8704C Kennan, John and Raymond Riezman. OPTIMAL TARIFF EQUUILIBRIA WITH CUSTOMS UNIONS.

8705C Feenstra, Robert C., and Tracy R. Lewis. NEGOTIATED TRADE RESTRICTIONS WITH PRIVATE POLITICAL PRESSURE.

8706C Brecher, Richard A. POLICY-INDUCED INFLOWS OF FOREIGN CAPITAL IN THE PRESENCE OF RIGID-WAGE UNEMPLOYMENT.

8707C Harrison, Glenn W., Richard Jones, Larry J. Kimbell, and Randall Wigle. HOW ROBUST IS APPLIED GENERAL EQUILIBRIUM ANALYSIS? 